OPEN ACCESS

Edited by:

Javier Carballo,

University of Vigo, Spain

Reviewed by:

Odile Tresse,

Oniris, France

Giorgia Perpetuini,

University of Teramo, Italy

*Correspondence: Avelino Alvarez-Ordóñez

avalordvet@gmail.com

Specialty section: This article was submitted to

Food Microbiology,

a section of the journal

Frontiers in Microbiology

Received: 25 February 2016

Accepted: 03 October 2016

Published: 18 October 2016

Citation:

Coughlan LM, Cotter PD, Hill C and

Alvarez-Ordóñez A (2016) New

Weapons to Fight Old Enemies: Novel

Strategies for the (Bio)control

of Bacterial Biofilms in the Food

Industry. Front. Microbiol. 7:1641.

doi: 10.3389/fmicb.2016.01641

\section{New Weapons to Fight Old Enemies: Novel Strategies for the (Bio)control of Bacterial Biofilms in the Food Industry}

\author{
Laura M. Coughlan 1,2, Paul D. Cotter ${ }^{1,3}$, Colin Hill2,3 and Avelino Alvarez-Ordóñez * \\ ${ }^{1}$ Teagasc Food Research Centre, Cork, Ireland, ${ }^{2}$ School of Microbiology, University College Cork, Cork, Ireland, \\ ${ }^{3}$ APC Microbiome Institute, Cork, Ireland
}

Biofilms are microbial communities characterized by their adhesion to solid surfaces and the production of a matrix of exopolymeric substances, consisting of polysaccharides, proteins, DNA and lipids, which surround the microorganisms lending structural integrity and a unique biochemical profile to the biofilm. Biofilm formation enhances the ability of the producer/s to persist in a given environment. Pathogenic and spoilage bacterial species capable of forming biofilms are a significant problem for the healthcare and food industries, as their biofilm-forming ability protects them from common cleaning processes and allows them to remain in the environment post-sanitation. In the food industry, persistent bacteria colonize the inside of mixing tanks, vats and tubing, compromising food safety and quality. Strategies to overcome bacterial persistence through inhibition of biofilm formation or removal of mature biofilms are therefore necessary. Current biofilm control strategies employed in the food industry (cleaning and disinfection, material selection and surface preconditioning, plasma treatment, ultrasonication, etc.), although effective to a certain point, fall short of biofilm control. Efforts have been explored, mainly with a view to their application in pharmaceutical and healthcare settings, which focus on targeting molecular determinants regulating biofilm formation. Their application to the food industry would greatly aid efforts to eradicate undesirable bacteria from food processing environments and, ultimately, from food products. These approaches, in contrast to bactericidal approaches, exert less selective pressure which in turn would reduce the likelihood of resistance development. A particularly interesting strategy targets quorum sensing systems, which regulate gene expression in response to fluctuations in cell-population density governing essential cellular processes including biofilm formation. This review article discusses the problems associated with bacterial biofilms in the food industry and summarizes the recent strategies explored to inhibit biofilm formation, with special focus on those targeting quorum sensing.

Keywords: biofilm, food, industry, quorum sensing, quorum sensing inhibitors 


\section{INTRODUCTION}

Certain bacteria develop a fortress or biofilm in the environments they colonize which provides shelter from antimicrobials and other sanitation procedures. A biofilm is formed when planktonic (or free/stand-alone) cells in an aqueous environment adopt a multicellular lifestyle by attachment to, and colonization of, a solid surface (Claessen et al., 2014). This may occur on a submerged surface or at the air-liquid interface (known as pellicle formation; $\mathrm{Wu}$ et al., 2012). Some bacteria begin biofilm formation without surface attachment via the aggregation of planktonic cells. Subsequent attachment of pre-formed aggregates to a solid surface results in true biofilm formation (Melaugh et al., 2016). The production of an extracellular matrix of DNA, carbohydrates, protein and lipids reinforces the sessile colony, facilitating the trapping of nutrients and protecting it against sanitation and even manual removal.

Biofilm formation is a serious problem in both the food and healthcare industries. Spoilage and pathogenic bacteria colonize, in the form of biofilms, the inside of mixing tanks, vats and tubing, compromising food safety and quality. In hospital settings, biofilm-forming bacteria persist in catheters, implants and on living tissues of patients suffering from chronic infections, such as those caused by Staphylococcus epidermis and Pseudomonas aeruginosa (Stewart and William Costerton, $2001)$. Despite the knowledge that the vast majority $(\sim 80 \%)$ of infectious and persistent bacteria are biofilm-formers (National Institutes of Health, 2002) and that in nature microorganisms are actually forming biofilms (Hall-Stoodley et al., 2004), most of the research carried out to date is focused on the properties and control of planktonic bacteria. In this literature review the knowledge available with respect to biofilm formation in the food industry and current biofilm control strategies is compiled and critically discussed with key focus on anti-biofilm approaches targeting the bacterial quorum sensing system.

\section{BACTERIAL BIOFILMS IN THE FOOD INDUSTRY}

In the food processing industry, microorganisms indigenous to certain foods generally do not harm the consumer and in some cases convey some benefit (e.g., fermented foods in which bacteria are intentionally introduced in the form of a starter culture). Therefore, efforts are not usually made to rid the processing environment of such microbes unless overgrowth or visible product spoilage occurs. Biofilms formed by pathogenic and spoilage microorganisms, however, serve as a reservoir of problematic microbial cells which may contaminate raw materials and food products during processing, resulting in food spoilage and economical losses for the producers (Winkelströter et al., 2014a). Persistence of unwelcome bacteria in industrial settings has been linked to such capabilities as antimicrobial and disinfectant resistance, tolerance of certain environmental stresses and biofilm formation. Consumers may be affected by reduced shelf life of the contaminated product and possible contraction of foodborne illnesses. Fresh, minimally processed foods are at high risk of bacterial contamination. The produce industry, responsible for providing raw and ready-to-eat fruit, vegetables and derived products, faces repeated contamination of food due to spoilage and pathogenic bacteria forming biofilms on industrial equipment or on the foods themselves (Jahid and Ha, 2012). In the dairy industry, a wide range of thermophilic and psychrophilic bacteria dwell along the different stages of processing and pasteurization. Persistent Bacillus cereus spores adhered to industrial surfaces act as a conditioning film promoting the prompt attachment of bacterial cells introduced into the system that would otherwise be removed by methods effective against planktonic cells (Marchand et al., 2012). Other thermophilic bacilli, such as Geobacillus spp., can grow at temperatures as high as $65^{\circ} \mathrm{C}$ and their heat-resistant spores prove problematic for the manufacture of milk powders (Palmer et al., 2010). Psychrotrophic bacteria complicate storage of milk and other dairy products as they can thrive at refrigeration temperatures. Pseudomonas are common spoilage psychrophiles which can reach high population numbers and form biofilms at low temperatures on walls of milk cooling tanks and pipelines prior to heat processing and often secrete heat-stable lipolytic and proteolytic enzymes which contribute greatly to milk spoilage (Marchand et al., 2009). In addition, Pseudomonas biofilms have been shown to be capable of providing shelter to other pathogenic bacteria (e.g., Listeria monocytogenes) in multispecies biofilms (Marchand et al., 2012). L. monocytogenes is an important psychrotrophic food pathogen associated with the dairy (as well as the produce and poultry) industry. It is an opportunistic gastrointestinal (GI) foodborne pathogen also capable of causing serious systemic infectious disease (listeriosis) in certain individuals including the very young, the elderly, in pregnant woman and immunocompromised patients (Hamon et al., 2006; Freitag et al., 2009). The seriousness of L. monocytogenes occupancy in food related environments and, subsequently, the human host is as a result of the bacteria's ability to multiply at a wide range of temperatures (Walker et al., 1990) and to tolerate and adapt to harsh environmental conditions such as osmotic stress (Dykes and Moorhead, 2000) and bile acid in the human GI tract (Gahan and Hill, 2014). This resistance to harsh conditions and its ability to form biofilms allow L. monocytogenes to persist in food processing environments, a serious threat to the food industry. Indeed, the persistence of several specific L. monocytogenes strains in food and food processing areas across seven out of 48 processing facilities in the Republic of Ireland over a period of 12 months has recently been demonstrated (Leong et al., 2014). Infections caused by food-associated pathogens capable of forming biofilms, e.g., L. monocytogenes, Campylobacter spp., Salmonella spp., seriously impact public health on a global scale with the annual health-care costs associated with common food-borne pathogens reaching $\$ 15.5$ billion in the USA per year (EFSA, 2009; Scallan et al., 2011; Hoffmann et al., 2015). Infection with Campylobacter species is the leading cause of food-borne bacterial gastroenteritis worldwide (World Health Organization, 2012) with Campylobacter jejuni claiming responsibility for the majority of those cases. Acute infection may lead to serious complications with long term consequences 
such as peripheral neuropathy symptoms typical of GuillainBarre syndrome (GBS) which has long been associated with Campylobacter infection (Nachamkin et al., 1998), reactive arthritis (Pope et al., 2007) and post-infectious irritable bowel syndrome (IBS; Schwille-Kiuntke et al., 2011). C. jejuni readily forms biofilm on food industry related surfaces (Teh et al., 2014), is frequently associated with poultry, and it has even been demonstrated that chicken juice increases biofilm formation on food industry-related equipment (Brown et al., 2014). Another serious pathogen is Salmonella enterica serovar Typhi (S. Typhi), the causative agent of typhoid fever, which is responsible for 21.7 million human infections and 217,000 deaths annually (Crump and Mintz, 2010) and is capable of forming biofilms (Kalai Chelvam et al., 2014) and persisting on materials often used in the food industry such as stainless steel, rubber and plastics, as comprehensively reviewed by Steenackers et al. (2012). Additionally, other Salmonella serovars able to form biofilm on food-related surfaces, such as S. enterica serovar Typhimurium (S. Typhimurium), cause a typhoid-like disease which is usually not fatal to healthy individuals but is commonly the source of poultry and meat products-related food poisoning (Jackson et al., 2013).

\section{BIOFILM FORMATION AND REGULATION}

Biofilm formation occurs over a series of sequential steps, in short: attachment (reversible and irreversible), cell-to-cell adhesion, expansion, maturation, and dispersal (Figure 1). Successful attachment to solid surfaces is governed by a slew of factors concerning both the bacterial cell and the surface of the potential biofilm site (reviewed by Chmielewski and
Frank, 2003; Persat et al., 2015). Biofilm-forming bacteria possess motility and anchoring appendages which enable movement through liquid and attachment to an appropriate surface such as flagella are proteinaceous structures protruding from the bacterial cell surface which enable swimming motility (Van Houdt and Michiels, 2010). Other adhesion molecules such as pili (or fimbriae) (Mandlik et al., 2008) and curli (Cookson et al., 2002) contribute to biofilm formation by enabling active attachment. Once attached, the bacteria proceed to colonize the surface through the formation of cellular aggregates known as microcolonies. Under permissive environmental conditions, microcolonies form two-dimensional dynamic structures as cell numbers increase, the first step toward structural organization on the chosen surface. This framework further matures into a defined architecture with cells arranged in simple or elaborate structures suited to thriving in their particular environment (Pilchová et al., 2014). Mature biofilm formations include flat monolayers, three-dimensional structures or mushroom- or tulip-like assemblies with low surface coverage and intervening water channels for nutrient and waste exchange (Karatan and Watnick, 2009; Jahid and Ha, 2012). Exopolymeric substance (EPS) is a gelatinous material encasing the cells of a biofilm which is composed of substances excreted by the cells themselves including proteins, polysaccharides, nucleic acids, lipids, dead bacterial cells, and other polymeric substances hydrated to 85-95\% water (Costerton et al., 1981; Sutherland, 1983). EPS functions to anchor to biotic and abiotic surfaces (Characklis and Marshall, 1990), concentrate nutrients from the surrounding environment within the biofilm, limit access of antimicrobial agents (contributing to resistance) and prevent the biofilm from desiccation (Carpentier and Cerf, 1993). The final stage in the biofilm life cycle involves the return of a number of adhered cells to the surrounding environment. In active detachment
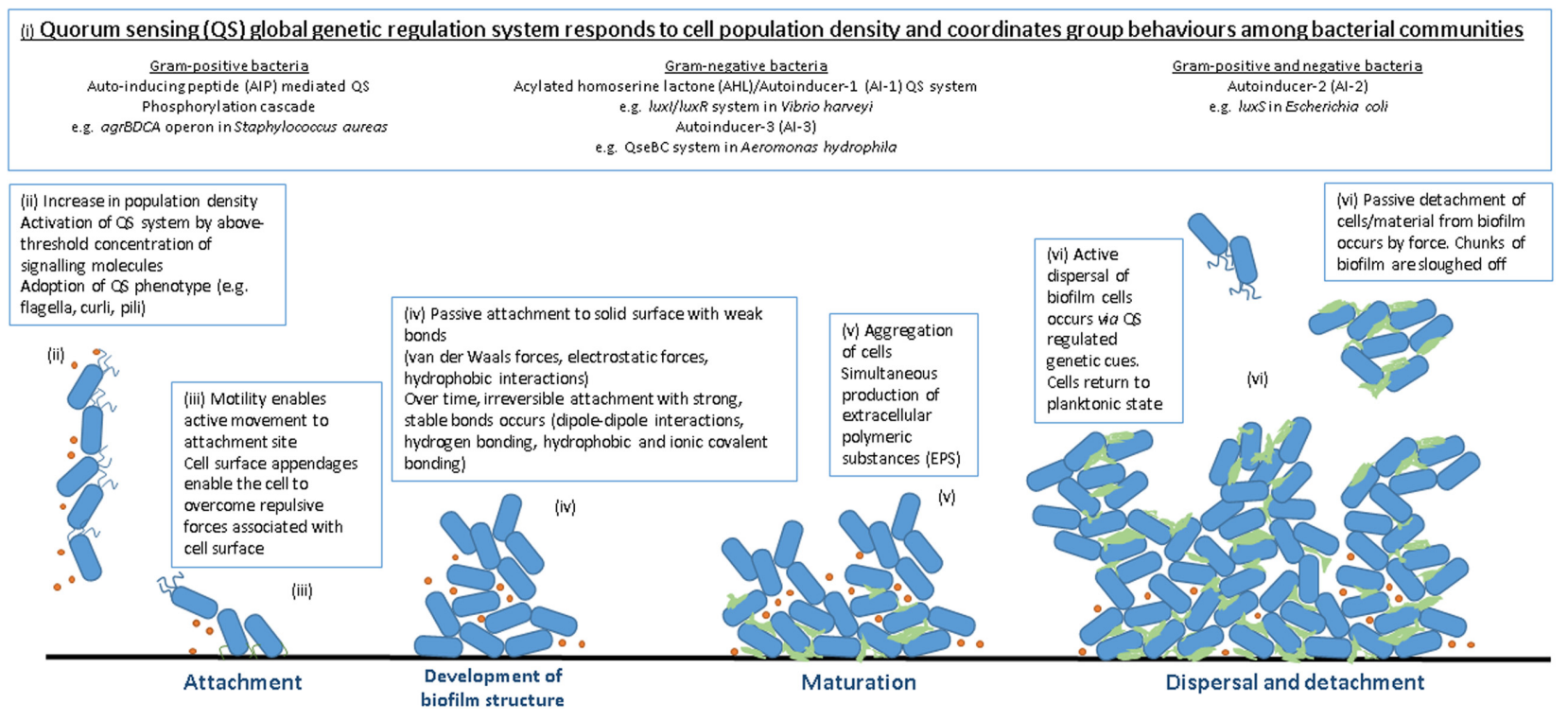

FIGURE 1 | Stages of biofilm formation. (i) QS signaling molecules (ii) high population density, high QS signal (iii) attachment to solid surface (iv) increase in cell numbers, irreversible attachment, development of biofilm structure (v) biofilm maturation and EPS production (vi) dispersal. 
cells revert back to their planktonic state and leave the biofilm in response to cellular cues (encouraging them to search for an additional attachment site when conditions are favorable). Passive detachment occurs as a result of environmental changes, such as nutrient availability and movement of surrounding liquid, and involves the sloughing off or erosion of parts of the biofilm by chemical means or force (Kaplan, 2010). Dispersal (reviewed by McDougald et al., 2012) facilitates the spreading of bacterial contaminants and the spoilage of foodstuffs by allowing the biofilm to act as a reservoir releasing cells back into the environment to carry out the cycle elsewhere.

Biofilms in nature and, indeed, in the food industry generally consist of multiple bacterial species as opposed to the mono-species biofilms usually cultured in laboratory studies (Yang et al., 2011). Life in a multispecies biofilm is advantageous, providing increased shelter and resistance to antimicrobials compared to corresponding single species biofilms (Burmølle et al., 2006). A study by van der Veen and Abee (2011) demonstrated that mixed species biofilms containing two L. monocytogenes strains and a Lactobacillus plantarum strain displayed increased resistance to the commonly used disinfectants benzalkonium chloride and peracetic acid in comparison to disinfection carried out on monospecies biofilms formed by the same strains. Wang et al. (2013) investigated the biocidal effect of the commercial sanitizer Vanquish (a quaternary ammonium compound-based product) and a chlorine solution prepared from Clorox (a germicidal bleach product) on mono- and multispecies biofilms formed by several Shiga toxin-producing Escherichia coli O157:H7 and $S$. enterica serovar Typhimurium strains. Increased resistance to sanitizers was observed in multispecies biofilms in which one of the strains was an EPS producer. EPS-producing strains of one species conferred protection to non EPS-producing strains of another, ultimately protecting both (to some degree) from sanitation. The results suggest the importance of the EPS component of bacterial biofilms in conveying resistance to the producer and in this case to the companion strains of mixed biofilms.

Cells that form biofilms have unique properties that enable them to do so, the expression of which is under the control of a global gene regulation system that responds to fluctuations in population density, known as quorum sensing (QS; Fuqua et al., 1994). Specific signaling molecules are produced and detected, governing community behavior. The higher the population density is, the higher the concentration of signaling peptides reached. When a minimal threshold stimulatory concentration of signaling molecules is reached, the QS system is activated and, thus, expression of QS-related genes occurs. QS is responsible for organizing the expression of many genes including those involved in essential cell processes, those encoding various virulence factors and also genes regulating biofilm formation. QS may be organized into three main sub-systems, classified by the type of signaling molecules employed: the acyl homoserine lactone (AHL) or autoinducer-I (AI-I) system is observed in Gramnegative bacteria, the peptide-mediated QS system in Grampositive bacteria and the autoinducer-2 (AI-2) system present in both Gram-negative and Gram-positive bacteria.
Acyl homoserine lactones were originally discovered in marine bacteria (Vibrio spp.) having been found to be responsible for bioluminescence regulation, and have since been identified in numerous Gram-negative bacteria. Synthesis of an AHL signaling molecule involving a LuxI type protein occurs when an acylcarrier protein-bound fatty acyl derivative is transferred to the amino group of $S$-adenosyl-methionine (SAM; Brackman and Coenye, 2015). AHL-mediated QS is well-described by Waters and Bassler (2005) using the control of the Vibrio fischeri luciferase operon as an example. Different bacteria produce different types of AHLs, controlling a range of functions. In addition, the same AHL may be produced by a number of bacteria spanning several genera. All AHLs contain the same homoserine lactone moiety but differ in the length and structure of their acyl groups. The diversity and specificity of AHL molecules, conveyed by the length, backbone and saturation of their fatty acyl side chains suggests their function in intraspecies communication. These N-acylated side chains vary in length from 4 (e.g., C4-HSL) to 18 carbons often with an oxo (e.g., 3-oxo-C6-HSL) or hydroxyl group (e.g., 3-hydroxyl-C6-HSL) on their third carbon atom and may also contain double bonds (Skandamis and Nychas, 2012). A huge variety of AHLs exists and has been reported in a wide range of bacterial species, including microorganisms associated with food and food processing. For example the common milk contaminant Pseudomonas fluorescens produces both C4-HSL and 3-oxo-C8-HSL AHL signaling molecules (Liu et al., 2007). Hafnia alvei, which is often isolated from cheese, produces the AHL N-3-oxohexanoyl HSL (Bruhn et al., 2004). In fact, AHL production by food-dwelling species has been associated with food spoilage. The detection of AHLs in some spoiled foods has led to suggestions that the secretion of certain proteolytic, saccharolytic and lipolytic enzymes, associated with food spoilage, is under the influence of AHL signaling (reviewed by Bai and Rai, 2011; Skandamis and Nychas, 2012).

It has been proposed that the AI-2 signaling system is used for both inter and intraspecies bacterial communication as AI-2 signaling molecules are non-specific. This system was first identified in Vibrio harveyi, an AHL-deficient strain which was capable of producing the bacterium's characteristic bioluminescence suggesting that another regulatory system was responsible for controlling its operation (Bassler et al., 1993). AI-2 synthesis involves two major enzymatic steps (Brackman and Coenye, 2015): $5^{\prime}$ methylthioadenosine nucleosidase (MTAN which is encoded by $p f s$ ) is produced and cleaves adenine from $S$-adenosyl-homocysteine (SAH). This results in the production of $S$-ribosyl-homocysteine (SRH), which is subsequently cleaved by LuxS to form 4, 5-dihydroxy-2, 3-pentanedione (DPD). Spontaneous rearrangements and modifications of DPD yield a combination of molecules collectively referred to as AI-2. The presence of $\operatorname{luxS}$, and thus AI-2 mediated QS, has been reported in some foodborne pathogens. Reeser et al. (2007) showed that AI-2 is critical for mature biofilm formation in C. jejuni M129 through the construction of a luxS deficient mutant. This strain, unable to produce the QS signaling molecule AI-2, was seen to have greatly decreased biofilm formation at the 48 and $72 \mathrm{~h}$ time points when compared to the wild type of the same strain, despite both having a similar growth rate. 
The group also showed that flagella are important for biofilm formation to the strain at hand by constructing a flaAb mutant, which also showed reduced biofilm formation at the 48 and $72 \mathrm{~h}$ time points and again no changes in growth rate. AI-2like activity has also been reported in L. monocytogenes and deletion of the luxS gene resulted in the bacterium forming thicker than normal biofilm, indicating a strong link between AI2 signaling and biofilm regulation in L. monocytogenes (Sela et al., 2006). More recently, the relationship between luxS and biofilm formation was demonstrated in E. coli by Niu et al. (2013) by comparing the biofilm forming abilities of a modified set of E. coli W3110 (a laboratory strain) with the wild type. The set included a luxS deficient mutant, a luxS mutant carrying an inducible plasmid containing luxS complement and a luxS mutant hosting a blank pBAD18 plasmid as a negative control. AI- 2 production, quantified by measuring bioluminescence induced in the reporter strain V. harveyi BB170, was observed to be higher in the luxS complement strain than the wild type and absent in both the luxS mutant and the negative control. Following on from this, biofilm formation in a continuous flow cell was assessed by differential interference contrast (DIC) light microscopy and confocal laser scanning microscopy (CLSM) for each strain. While the luxS mutant and the negative control were found to form compact clusters, the luxS complement formed tall, thick biofilms and the wild type a combination of the observed phenotypes. The results indicate a strong correlation between AI-2 expression and quality of biofilm, suggesting the key role of AI-2 mediated QS in biofilm formation in E. coli W3110. As well as the Gram-negative microbes mentioned above, luxS has also been studied in Grampositive bacteria. Bacillus subtilis, a spoilage bacterium regularly isolated from dairy products and processing facilities (reviewed by Gopal et al., 2015) was reported to regulate biofilm formation through luxS-mediated quorum sensing (Duanis-Assaf et al., 2015).

The presence of a third autoinducing molecule (AI-3) has been reported in Gram-negative bacteria such as E. coli, Klebsiella pneumoniae, Shigella spp., Salmonella spp., and Enterobacter cloacae (Walters et al., 2006). Sperandio et al. (2003) first described AI-3 when studying gene expression of the foodborne pathogen E. coli O157:H7 in response to a eukaryotic cell signal. The group found AI-3 (presumed to be LuxS-dependent) to be responsible for the activation of virulence gene expression, including flagella regulation genes, and proposed AI-3 as a possible agent of cross-communication between bacterial and host cells as substitution of either AI3 or the mammalian hormone epinephrine (Epi) restored the virulence phenotype in a luxS deficient mutant, suggesting that AI-3 and Epi employ the same signaling pathway. A later study by Walters et al. (2006) showed that luxS mutants were forced to synthesize homocysteine via an alternative pathway using oxaloacetate and that culturing the mutants in media supplemented with L-aspartate alleviated the demand for oxaloacetate and restored AI-3 production without affecting AI2 production. This work demonstrates that AI-3 production is not LuxS-dependent and the true mechanism for synthesis of this molecule is yet unclear (reviewed by Bai and Rai, 2011).
In Gram-positive bacteria, QS communication is mediated by autoinducing peptides (AIPs; Bai and Rai, 2011). Bacteria employing this system do so with unique, species-specific signaling molecules, suggesting that peptide-mediated signaling enables intraspecies communication alone. The biphasic mode of infection employed by Staphylococcus aureus is an elegant example of QS signaling in Gram-positive bacteria, reviewed by Waters and Bassler (2005). Examples of bacteria employing QS peptide signaling are the opportunistic foodborne pathogen Clostridium perfringens, for the regulation of virulence, sporulation, toxin production (Ma et al., 2015) and biofilm formation (Vidal et al., 2015), and L. monocytogenes for virulence, invasion and biofilm regulation (Riedel et al., 2009; Abee et al., 2011).

\section{STRATEGIES UNDERTAKEN TO PREVENT BIOFILM FORMATION AND REMOVE EXISTING BIOFILMS}

The best strategy to eradicate bacterial biofilms from food-related environments is to prevent their formation. This can be achieved by preventing the presence of biofilm forming bacteria in critical areas, e.g., sterile manufacture (aseptic processing) or terminal sterilization of parenteral preparations and equipment. In most cases, especially in food production, sterility of the environment is neither possible nor cost-effective and so measures are taken to instead reduce the numbers of harmful and biofilm-forming bacteria in the production area. In food production facilities, detailed hygiene practices are carried out by trained staff in an effort to prevent the introduction of microbes into the processing and finishing areas. Daily sanitation/disinfection processes are carried out in every food manufacturing plant to eliminate microbes that have made it inside and aim to prevent colonization or persistence. The measures involved incorporate mechanical, chemical, and thermal processes to prevent biofilm formation as efficiently as possible.

\section{Cleaning and Disinfection}

Measures such as Good Manufacturing Practice (GMP) and Hazard Analysis Critical Control Point (HACCP) schemes (Sharma and Anand, 2002) are active in food processing facilities to ensure that food quality and safety meet high standards. Documented and validated cleaning procedures exist and their implementation is legally enforced via inspection by regulatory bodies. A general cleaning procedure for food processing and production areas involves six necessary sequential steps: preclean (physical), washing (detergents), rinsing, sanitation, final rinsing, and drying (Safefood, 2012). The first of these is a preparatory measure known as a gross (or dry) clean, the aim of which is to manually remove all bulk soil, packaging materials and tools, essentially all unnecessary equipment and large debris. Equipment to be manually cleaned must also be disassembled and laid out for ease of access during the subsequent steps. In dairy manufacturing plants (DMPs), and others, a control protocol known as Clean-In-Place (CIP) is implemented to reduce biofilm formation and microbial load in general (Bremer et al., 2006). 
CIP is a semi- or fully automated programmed cycle of timed rinsing and cleaning stages for the efficient cleaning of equipment interiors that are inaccessible or their manual cleaning ineffectual. Next, a pre-rinse is carried out during which the equipment and area is rinsed with water until surfaces are visibly clear of soils and deposits. Higher water pressure may be used for removal of stubborn soils though care must be taken not to cause cross-contamination through splash-back or migration of aerosolized water onto other surfaces. Following this step, excess water must be removed to avoid pooling around or backing up of drains and to prevent dilution of the cleaning solutions/solvents used in later steps. The next step involves the application of a detergent to remove remaining food deposits such as proteins and grease, layers in which bacteria can survive and re-enter the system post-cleaning. Detergents may be applied in the form of foam or aerosol spray, at an appropriate concentration, and adequate contact time with surfaces must be allowed to ensure efficient action. Alkaline and acidic products are commonly used detergents in the food industry (Simões et al., 2010) with alkalis showing success in the removal of Pseudomonas putida biofilms from stainless steel (Antoniouand and Frank, 2005). In the following step of the cleaning protocol, detergent and lifted food deposits are removed from the area through rinsing with water at the lowest effective pressure. The surfaces should be visibly clean and free of layers of soil and any marks or residues left by the detergent. Again, excess water is evacuated. At this stage, disinfection is performed to reduce microbial load. Disinfectants may be applied as a liquid spray directly to surfaces or as a fine mist via aerial fogging to target airborne microorganisms, which then also settles on and disinfects surfaces. The ambient temperature and the contact time between the disinfectant solution and the surface should be factored into the procedure to maximize the biocidal effect. Some commonly used disinfectants that have demonstrated competence in reducing biofilms in the food industry include hydrogen peroxide $\left(\mathrm{H}_{2} \mathrm{O}_{2}\right)$, sodium hypochlorite $(\mathrm{NaClO})$, which is also an effective sanitizer, ozone, and peracetic acid (Srey et al., 2013). Toté et al. (2010) found $\mathrm{H}_{2} \mathrm{O}_{2}$ and $\mathrm{NaClO}$ to be effective in the removal of $S$. aureus and $P$. aeruginosa biofilm cells and EPS matrix from 96-well assay plates. It has been demonstrated that ozone and especially $\mathrm{H}_{2} \mathrm{O}_{2}$ are effective at inhibiting Vibrio spp. biofilms associated with seawater distribution networks used in fish-processing plants (Shikongo-Nambabi et al., 2010) and also that peracetic acid is active against L. monocytogenes biofilms (Cabeça et al., 2012). Although sanitizers, which possess the combined action of both detergents and disinfectants, are used in some cleaning protocols, it is believed that splitting these steps and introducing an intermediate rinsing step is more effective than sanitizing alone. Even so, sanitizers remain in use and sanitizing compounds such as $\mathrm{NaClO}$ and Spartec, a quaternary ammonium compound (QAC), have been found to be effective against B. cereus biofilms when applied under specific cleaning protocols (Peng et al., 2002). The next stage in the cleaning process is the rinsing away of the disinfectant. Most disinfectants are safe to leave on surfaces that do not have direct contact with food, however water of a high quality is used to rinse food contact surfaces and in some cases non-contact surfaces as well. Finally, the equipment is dried to remove rinsing water. Although regular application of cleaning agents reduces microbial populations (Jahid and Ha, 2012), it is normally not efficient at removing mature biofilms. Cleaning and disinfection can remove unwanted bacteria before they have a chance to attach to a surface and form a biofilm, however, due to the fast rate at which attachment and biofilm formation occurs, they are not completely efficient at preventing contamination of food processing environments. In addition, due to residual soil and previous biofilm matrix present on surfaces, sanitation may not be effective alone and the use of disinfectants may select for resistant bacteria (Simões et al., 2010). Interestingly, bacteria residing in biofilm matrices are remarkably (100-1000 times) more resistant to cleaning and sanitation processes than planktonic cells (Gilbert et al., 2002) and it is noteworthy that the majority of chemical disinfectants that are commonly implemented in food, industrial, clinical and domestic cleaning procedures are based on bactericidal studies performed on planktonic cells (Annonymous, 1997). The reasons for increased resistance of bacteria in biofilms are not yet fully understood but the phenomenon has been well-documented (Nickel et al., 1985; Luppens et al., 2002).

\section{Processing Equipment Materials and Design}

Facility design and staff training is highly important for minimizing cross-contamination between high risk and lowrisk areas within the plant that can be caused by unchecked foot traffic between stations. Zone establishment segregating exposed product areas from packaging areas, the limiting of access to high-risk areas to authorized personnel and strict garbing and hand-washing requirements on entering restricted areas all play a role in maintaining hygiene standards. Cross departmental knowledge and awareness of potential consequences of contamination ensures compliance and lessens the likelihood of accidental breach of policy. Included in facility design is the selection of appropriate materials for use in the processing areas. Materials for the design of food processing and manufacturing equipment are selected based on a number of factors, most importantly ease of cleaning for reduction of contamination and associated risks. Materials should also be reasonably resistant to chemical and age-related corrosion for maintenance of a smooth and easy-to-clean surface and to prevent contamination risks and downtime associated with frequent replacement of damaged/corroded equipment. Surface topography is important as microorganisms may attach or find shelter in cracks, scratches, and corners of equipment making them extremely difficult to remove (Bremer et al., 2006). Inert metals are commonly used in the food industry, especially stainless steel and aluminum. Stainless steels contain alloys such as chromium to increase resistance to corrosion (rusting). Type 316 steel is especially resistant to chloride environments and is more costly than type 304 steel which is more commonly used due to its versatility and ease of forming. The smooth surface finishes that are achieved by rolling and polishing steel make it a very valuable material for the production of food processing equipment. Another commonly employed metal is 
aluminum, a light weight and economical material which is also highly resistant to corrosion, especially from acids. Aluminum, however, is susceptible to scratching and damage due to a low surface hardness and to corrosion by alkalis, traits which allow the smooth surface to be compromised, increasing the risk of contamination. In milk processing facilities equipment is required to be resistant to corrosion in alkaline and/or acidic conditions (Marchand et al., 2012) and so stainless steel is normally used. Non-metal materials are employed for moving and disposable equipment such as conveyor belts, containers and cutting boards and for components and attachments where soft material is required such as for seals, gaskets, membranes, and piping. These materials are most commonly elastomers (rubbers) such as ethylene propylene diene monomer rubber (EPDM), nitril butyl rubber (NBR, aka Buna- $\left.\mathrm{N}^{\circledR}\right)$, silicon rubber or fluoroelastomer (Viton) and plastics such as polypropylene (PP), polycarbonate (PC), high-density polyethylene (HDPE), unplasticized polyvinyl chloride (PVC), and fluoropolymers such as polytetrafluoroethylene (PTFE aka Teflon ${ }^{\circledR}$; Faille and Carpentier, 2009; Marchand et al., 2012). Unfortunately, certain bacteria are capable of forming biofilms on these food-approved materials. This attachment is aided by improper cleaning of such materials as soil or debris remaining post-sanitation may form a conditioning film for subsequent attachment of planktonic bacteria to this site (Marchand et al., 2012). Surface preconditioning using surfactants that modify the chemical properties of surfaces have been used to prevent bacteria from attaching (Simões et al., 2010). Indeed, more than 90\% inhibition of $P$. aeruginosa adhesion to stainless steel and glass was reported by Cloete and Jacobs (2001) upon treating the surfaces with ionic and anionic surfactants. Biosurfactants, microbial compounds that act as surfactants, may also be employed to reduce or prevent adhesion of problematic biofilm-forming bacteria (Banat et al., 2010). Zezzi do Valle Gomes and Nitschke (2012) investigated the efficacy of biosurfactants such as surfactin from B. subtilis and rhamnolipids from $P$. aeruginosa in reducing the adhesion and disrupting the pre-formed biofilms of the pathogenic foodassociated bacteria L. monocytogenes, S. aureus, and Salmonella Enteritidis. The biosurfactants studied were effective in the disruption of biofilms formed on polystyrene microplates by all species individually and in the disruption of a multispecies biofilm containing all three. The action of the surfactants in preventing bacterial adhesion was effective against pure culture biofilms of each species. However, they were shown to have reduced impact in preventing adhesion of the mixed bacterial culture to the plates, again highlighting the advantages bestowed to bacteria residing in a multispecies habitat. Gu et al. (2016) reported the effective removal of established $P$. aeruginosa PAO1, S. aureus ALC2085 and uropathogenic E. coli ATCC53505 biofilms formed on an antifouling surface. The group used shape memory polymers (SMPs) -a type of material specially designed to remember a particular shape, manipulated into keeping a temporary shape and then coaxed back into its original form by external activation- as an attachment surface for the microbes to form biofilm and, upon triggering of SMP shape change, the amounts of adhered cells were dramatically reduced $(99.9 \%$ in the case of $P$. aeruginosa). This type of study takes anti-biofilm surface topography research to a new level, achieving the physical displacement of established biofilms with minimal (if any) effect on the surrounding environment using biocompatible materials and may in time be applicable to equipment and facility design in the food industry.

\section{Processing Conditions}

Another approach to prevent biofilm formation of bacteria present in the production environment involves carrying out the process under conditions unfavorable to biofilm formation. Temperature appears to influence bacterial attachment to solid surfaces. Cappello and Guglielmino (2006) studied the adhesion of $P$. aeruginosa ATCC 27853 to polystyrene plates at 15, 30 , and $47^{\circ} \mathrm{C}$, reporting a dramatic difference in adhesive ability (measured as percentage hydrophobicity) between cells cultured at the higher temperatures of 30 and $47^{\circ} \mathrm{C}$ and cells cultured at $15^{\circ} \mathrm{C}$. Temperature-dependent variation in biofilm formation was also observed among L. monocytogenes strains by Di Bonaventura et al. (2008). In addition to temperature, nutrient availability in a given environment has been shown to influence the quality of biofilms formed. In general, studies have demonstrated that biofilms formed under low nutrient availability or starvation conditions are superior to biofilms formed under high nutrient availability, with bacteria in nutrient rich surroundings failing to form biofilms in some cases (Petrova and Sauer, 2012). Zhou et al. (2012) reported enhanced (thicker and more complex) biofilm formation of L. monocytogenes in a poor minimal essential medium (MEM) supplemented with glucose compared to the biofilm formed by the same strain in nutrient rich brain heart infusion (BHI) broth. Similar results were seen previously by Dewanti and Wong (1995) who cultured E. coli 0157:H7 biofilms on stainless steel chips in broths of varying nutrient availability. The group reported the formation of biofilms with high cell numbers that formed quickly and produced thicker EPS when grown in nutrient-scarce media in comparison to those formed in tryptic soy broth (TSB). Biofilm formation may also be altered by the $\mathrm{pH}$ of the surrounding media. Decreased cell attachment was reported (Tresse et al., 2006) for L. monocytogenes biofilms grown at $\mathrm{pH} 5$ than for those at $\mathrm{pH} 7$, which was later (Tresse et al., 2009) attributed to $\mathrm{pH}$ dependent flagellation in L. monocytogenes observed as a downregulation of flagellin synthesis in acidic conditions. O'Leary et al. (2015) investigated the effect of low $\mathrm{pH}$ on the biofilm forming capacity of four acid-adapted S. Typhimurium DT104 strains, only one of which formed biofilms at both $\mathrm{pH} 5$ and 7, with the remaining three strains unable to form stable biofilms at the mildly acidic $\mathrm{pH}$ of 5 . Gene expression under the distinct $\mathrm{pH}$ conditions was also examined showing that genes involved in biofilm formation were expressed at higher levels at $\mathrm{pH} 5$ than at neutral $\mathrm{pH}$ for all isolates, despite the lack of biofilm formation observed in three out of four strains. These results propose the existence of a separate set of genes which aid biofilm formation under acidic conditions and which were not present in three of the strains at hand. Despite the successes of biofilm-limiting conditions in laboratory experiments, in most cases, application of these findings to the food industry is not appropriate as altering process conditions is likely to impact product quality. 


\section{Physical Approaches}

Physical force is also employed in the food industry for the reduction of microbial load and the removal of biofilms. Brushes, water jets, and turbulent flow in pipelines are used to administer force to susceptible surfaces during cleaning protocols (Safefood, 2012). In addition, in recent years, other physical-based novel technologies have been developed to reduce the microbial load on surfaces or remove biofilms. Plasma treatment involves bombarding surfaces with a partially ionized gas and has been used successfully as a disinfectant targeting planktonic microbes (Laroussi, 1996). A study carried out by Vandervoort and BrellesMariño (2014) demonstrated the efficacy of plasma-mediated inactivation against a $P$. aeruginosa biofilm grown on borosilicate glass in continuous culture, better to mimic natural and industrial environmental conditions under which problematic biofilms are generally formed. The group reported changes in biofilm structure post-plasma treatment which they associated with decreased adhesion of the biofilm to the colonized surface. Ultrasonication was found to be successful for the removal of biofilms when used in combination with other anti-biofilm agents such as antibiotics (Peterson and Pitt, 2000), ozone (Baumann et al., 2009) and the chelating agent ethylenediaminetetraacetic acid (EDTA) (Oulahal et al., 2007), reviewed by Srey et al. (2013). A greater understanding of the intricacies of a biofilm (species involved, structure, composition of EPS, etc.) leads to improved, more focused efforts to remove existing biofilms and prevention of biofilm formation of studied species. Manual removal of cells from a biofilm and simple analysis by cell plating followed by microscopic analysis of fluorescently labeled or stained lab-grown biofilms (cultured in high throughput matrices such as 96-well plates or glass/stainless steel coupons) provides detailed information on both the microbes involved and on biofilm architecture. Quantification of live cells (e.g., MTT staining) or biofilm formed (crystal violet staining) may be carried out on cultured biofilms to quantify total biomass, assess external factors and environmental conditions affecting biofilm formation and to evaluate the success of biofilm removal and inhibition strategies, as reviewed by Stiefel et al. (2016). Additionally, polymerase chain reaction (PCR)-based methods allow for rapid detection of pathogens and spoilage bacteria from a biofilm sample, as reviewed by Winkelströter et al. (2014b). Dzieciol et al. (2016) used culture independent methods (pyrosequencing of 16S rRNA gene amplicons) to characterize the microbial communities of floor drain water from four sources in a cheese processing facility for the purpose of monitoring L. monocytogenes persistence. Other useful technologies include biofilm detectors which are used to monitor biofilm formation on a surface and can enable intervention in the early stages of biofilm formation in an attempt to prevent its progression into a mature biofilm. Pereira et al. (2008) developed a surface sensor capable of detecting early biofilms, and further developed the technology to monitor cleaning-in-place procedures (Pereira et al., 2009). AlAdawi et al. (2016) employed CLSM and denaturing gradient gel electrophoresis (DGGE) to study mono and dual species biofilm formation of food-related pathogens on stainless steel and raw chicken meat and the transfer of microbial cells from the abiotic to the biotic surface. As biofilms contribute hugely to cross contamination between equipment in the food industry and the products themselves, such studies are critical in developing novel and appropriate techniques for detecting and analyzing biofilms.

The majority of current strategies aim to prevent introduction of microbes into the food processing environment, contributing also to reduce the risk of biofilm formation through removal of soils and food deposits on processing equipment as improperly cleaned surfaces with soil build-up serve as attachment sites for biofilm forming bacteria. However, most of these approaches do little to remove existing biofilms formed by persistent bacteria within production areas, for example biofilms in milk tanks and tubing that are heat tolerant or thermophilic and are resistant to the high temperatures of pasteurization. Periodic cleaning of equipment requires halting production, drainage and cleaning which negatively impacts output and is not ideal in terms of hygiene.

\section{Enzymes}

Enzyme-based detergents are used to improve efficacy of disinfectants against bacterial biofilms. Enzymes can target cells in the biofilm matrix and can cause the matrix to become looser and break up. They can also trigger cell release actions in the biofilm enveloped cells, causing an amount of cells to break off from the biofilm. Enzymes have some role in targeting the bacterial cells encased within a biofilm, however the main function of enzymes is to degrade the lipid, carbohydrate and DNA components of the extracellular matrix, severing the links between cells and subsequently separating them, allowing rapid deterioration of the biofilm integrity (see Figure 2A). Disinfectants can then act more powerfully to kill cells that were once embedded in the matrix of the biofilm EPS and can also target released cells which have been forced into the planktonic state by the enzymes action. The types of enzymes commonly employed depend on the composition of the biofilm one is attempting to eradicate and include proteases, cellulases, polysaccharide depolymerases, alginate lyases, dispersin $\mathrm{B}$ and DNAses (Bridier et al., 2015). As EPS is a heterogenic matrix, a combination of enzymes with different target substrates is used, and even further tweaking of the mixture is required for multispecies biofilms where there exists a variety of substrates. A study by Walker et al. (2007) demonstrated the success of an enzyme mix against a multispecies biofilm formed on brewery dispense equipment. Additional studies have been carried out which highlight the potency of enzyme-based approaches against food related bacterial biofilms. Mimicking a meat processing environment, Wang et al. (2016) induced biofilm formation by a cocktail of seven Salmonella spp. strains isolated from meat processing surfaces and poultry grown in meat thawingloss broth (MTLB) and on stainless steel. They reported the successful removal of said biofilm through treatment with cellulase followed by immersion in cetyltrimethyl ammonium bromide (CTAB). Oulahal-Lagsir et al. (2003) reported a 61$96 \%$ removal of $E$. coli biofilms formed on stainless steel in milk when they synergistically exposed the biofilms to both proteolytic and glycolytic enzymes and ultrasonic waves for 10 s. The action of polysaccharidases against $P$. fluorescens biofilms and the efficacy of serine proteases in the removal 

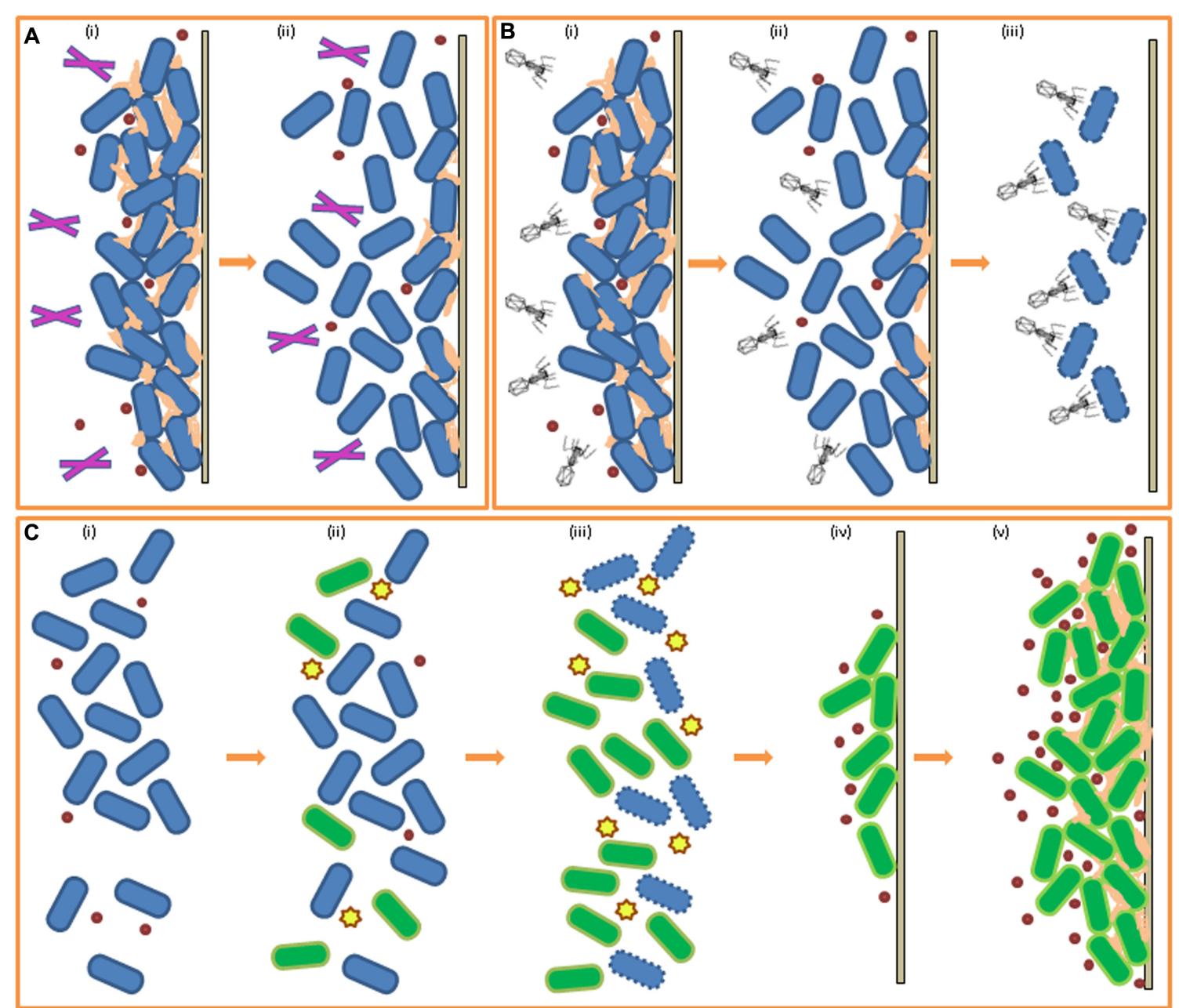

FIGURE 2 | Biofilm control through enzymes, phage, and bacteriocins. (A) Effect of enzymes on pre-existing biofilm (i) biofilm formed, EPS production, addition of enzymes (ii) breakdown of EPS and biofilm reduction by enzymatic action. (B) Effect of bacteriophage on pre-existing biofilm (i) biofilm formed, EPS production, addition of phage (ii) degradation of EPS by phage, reduction of biofilm (iii) bacterial cells in biofilm targeted by targeted for infection by phage. (C) Effect of bacteriocins and competitive exclusion on biofilm-forming cells (i) planktonic cells of species A (blue) (ii) addition of bacteriocin-producing species B (green) (iii) targeting of species A by bacteriocins, increase in number of species B cells (iv) increase in QS molecule concentration for species B, attachment to solid surface (v) biofilm formation of species $B$ in place of species $A$.

of Bacillus biofilms from stainless steel chips was reported by Lequette et al. (2010). Commercial $\alpha$-amylases have been found to be effective at both removal and inhibition of $S$. aureus biofilms (Craigen et al., 2011). Another study investigated the potential for commercial proteases and amylases to break down the EPS of biofilms formed by P. fluorescens on glass wool (Molobela et al., 2010). The group examined the composition of the EPS and selected appropriate enzymes, which were evaluated as anti-biofilm agents. As the EPS in this case consisted predominantly of proteins, commercial proteases were found to be most effective at biofilm removal in this study. Enzymes sourced from fungal strains were also shown to be successful at removal of biofilms formed by $P$. fluorescens on glass coupons (Orgaz et al., 2006). When employing enzymebased products, one must consider the reaction of enzymes with food products or ingredients during processing, for example,
Augustin et al. (2004) found several commercial enzymes to be useful as cleaning products against biofilms of common dairy-associated spoilage bacterium $P$. aeruginosa. However, the activity of proteinase enzymes is reduced in the presence of milk and so the performance of the enzyme was not sufficient to encourage further development of a product. DNases, which degrade the extracellular DNA component of EPS, have also been studied as enzyme-based formulations for battling biofilms. Extracellular DNA is a crucial component of the bacterially produced EPS constituting the biofilm matrix, with speciesdependent roles in cell aggregation and intercellular connection, maintenance of the structure of the biofilm, and as an adhesive with some antimicrobial properties (reviewed by Flemming and Wingender, 2010). Brown et al. (2015) showed that the exogenous addition of DNase I led to rapid degradation of extracellular DNA and removal of a C. jejuni biofilm attached 
to stainless steel (to mimic a food processing environment). C. jejuni is capable of both formation of de novo biofilms as well as integration into existing biofilms occupied by other species in food related environments (Teh et al., 2014). The use of DNase I in this study against a $C$. jejuni biofilm was successful in both swift removal of the biofilm from its attached surface and in prevention of reattachment and de novo synthesis of a new biofilm for up to $48 \mathrm{~h}$ on a DNase I treated surface. Kim et al. (2017) showed that DNase I significantly inhibited the biofilm forming capabilities of one C. jejuni and three Campylobacter coli strains when added at the beginning of biofilm formation and also disrupted $72 \mathrm{~h}$ old mature biofilms of these strains, isolated from commercially bought raw chickens. This study further contributes to the assumption that extracellular DNA plays a key role in Campylobacter biofilm formation, highlighting DNase I as a promising candidate for the control of Campylobacter biofilms. Zetzmann et al. (2015) reported the formation of DNase I-sensitive biofilms by $L$. monocytogenes EGD-e at low ionic strength, conditions which are commonplace in food processing. DNase I was also found to be effective against biofilm formation in a study carried out by Harmsen et al. (2010) in which its employment inhibited initial attachment of L. monocytogenes cultures to glass and delayed biofilm formation in polystyrene microtiter plates.

\section{Bacteriophage}

Bacteriophage are bacteria's natural enemies and so have potential for use against pathogenic and spoilage bacteria in food (reviewed by Endersen et al., 2014). Phage offer special promise when it comes to eradicating biofilms as they are capable of penetrating the matrix and diffusing through the mature biofilm and, once inside, express their antibacterial properties (Briandet et al., 2008; Donlan, 2009), as illustrated in Figure 2B. Work has also been carried out against biofilms with both natural and engineered phage (reviewed in Simões et al., 2010). Phage are extremely specific to their bacterial host and this specificity is important for use in control of undesirable bacterial species in foods as beneficial bacteria are often used in food production, especially starter cultures in fermented foods, in which cases the preservation of the beneficial bacteria is essential for finished product quality (Guenther et al., 2009). Lytic phage are better suited to biocontrol purposes as, unlike lysogenic phage, they engage the lytic pathway to the detriment of the bacterial cell. LISTEX ${ }^{\mathrm{TM}}$ is a commercial product developed from the bacteriophage P100 which induces cell lysis and disintegration of the EPS by enzymatic action. It is a natural and non-toxic phage product active against $L$. monocytogenes and is recognized in the USA by the United States Department of Agriculture (USDA) for use in all food products (Listex, 2006). Soni and Nannapaneni (2010) treated 21 L. monocytogenes strains, which had formed biofilms on stainless steel coupons, with bacteriophage P100 and reported a significant reduction in cell numbers of the listerial biofilms. Lytic phage $\varphi$ S1 was shown to be effective against early stage biofilms of P. fluorescens (Sillankorva et al., 2004). The biofilms were 5 days old when treated with the bacteriophage $\varphi$ S1 and this resulted in an $80 \%$ removal of the biofilm (under optimal conditions). Another study demonstrated the efficacy of phage $\mathrm{K}$ plus six derivatives in the removal and prevention of S. aureus biofilms in microtitre plates (Kelly et al., 2012). $\mathrm{CHAP}_{\mathrm{K}}$, a peptidase derived from the phage $\mathrm{K}$, successfully disrupted and eliminated staphylococcal biofilms on microtitre assay plates within $4 \mathrm{~h}$ (Fenton et al., 2013). In a study by Lu and Collins (2007), E. coli-specific bacteriophage T7 was engineered to express intracellularly a biofilm-degrading enzyme, dispersin B, which targets an adhesin required for biofilm formation by E. coli and Staphylococcus spp. during infection, so that when added to the culture medium the phage was able to simultaneously attack the bacterial cells in the biofilm (as phage do) and also able to penetrate the biofilm matrix through degradation of EPS. The group demonstrated that the approach involving the engineered phage was markedly more efficient at biofilm disruption than the use of a non-engineered phage. Building on this work, enzymatic phage designed with multiple EPS targets could greater improve efficiency of this technique.

\section{Bacteriocins}

Ribosomally synthesized antimicrobial peptides secreted by bacteria, known as bacteriocins, or the bacteriocin-producing strains themselves, may be added to culture media to impede initial cell adhesion and biofilm formation of certain susceptible bacteria (da Silva and De Martinis, 2013), as illustrated in Figure 2C. Nisin, a bacteriocin secreted by Lactococcus lactis, is a safe and effective additive for certain food products (Cotter et al., 2005) and a commercialized form, Nisaplin ${ }^{\circledR}$, is produced by Dupont (formerly Danisco). Nisin A, produced by a L. lactis UQ2 isolated from Mexican style cheese, was investigated for its activity against $L$. monocytogenes biofilm formation on stainless steel coupons (García-Almendárez et al., 2008). Both $L$. lactis UQ2 cells and a spray-dried crude bacteriocin fermentate (CBF) of $L$. lactis $\mathrm{UQ} 2$ were assessed using fluorescent in situ hybridization (FISH) with specific labeled probes to distinguish between cells of both cultures. The study found that a combination of lactic acid and nisin A, both produced by L. lactis $\mathrm{UQ} 2$, was successful in the restriction of L. monocytogenes biofilm formation by competitive exclusion indicated by the observation of reduced numbers of L. monocytogenes cells on the steel chips incubated in co-culture with L. lactis UQ2 compared to the Listeria-only control. In a study by Field et al. (2015), a modified nisin variant with enhanced antimicrobial and anti-biofilm activity against the canine pathogen Staphylococcus pseudintermedius was shown to be more effective than the original peptide from which it was derived. The bioengineered bacteriocin was capable of both impairing biofilm formation and reducing pre-existing biofilms of $S$. pseudintermedius. Lactobacillus sakei is a bacteriocin producing lactic acid bacteria commonly used in the preservation and fermentation of meat products (Champomier-Verges et al., 2001). L. monocytogenes biofilm formation in the presence of an L. sakei strain (L. sakei 1 ) and of the cell-free supernatant (CFS) of $L$. sakei 1 containing bacteriocin, sakacin 1, was assessed on stainless steel coupons (Winkelströter et al., 2011). A non-bacteriocin producing L. sakei 
strain and its bacteriocin-free CFS were also co-cultured with the L. monocytogenes biofilms separately as controls. The bacteriocinproducing strain and its CFS were both efficient in the inhibition of the initial steps of biofilm formation as they were observed to decrease the number of adhered cells present on the stainless steel coupons. However, after $48 \mathrm{~h}$ of incubation re-growth of adhered listerial cells was observed in the culture containing the sakacin 1-CFS only and so, inhibitory activity cannot safely be attributed to bacteriocin-production alone. The results are still promising indicating that L. sakei and its bacteriocin may be beneficial for the inhibition of early biofilm formation by L. monocytogenes. In a similar study, Pérez-Ibarreche et al. (2016) investigated the effect of bacteriocin-producing L. sakei strain CRL1862 on biofilms formed by L. monocytogenes FBUNT (isolated from artisanal sausages) on industrially relevant stainless steel and polytetrafluoroethylene (PTFE) surfaces. This L. sakei strain was found to be effective at biofilm inhibition, leading to the suggestion by the authors of the pre-treatment of food processing equipment with the Lactobacillus or its bacteriocin as a potential method of preventing Listeria adhesion to the surface concerned.

Many bacteriocins are produced by lactic acid bacteria which are commonly employed as starter cultures for the production of various fermented foods (Buckenhüskes, 1993). In addition to the acclaimed safety profile of LAB for use in food production, their metabolism is known to offer sensory improvements to fermented food products (Leroy and De Vuyst, 2004) and the presence of selected strains may also inhibit the growth of some foodborne spoilage and pathogenic bacteria, making LAB a practical addition to food preparations and processing cycles. In a recent study, recombinant lectin-like proteins that were identified by genome mining of probiotic Lactobacillus rhamnosus GG and over-expressed in E. coli were found to disrupt biofilms formed by S. Typhimurium ATCC14028 on polystyrene pegs (Petrova et al., 2016). Although, the authors carried out this study with clinical applications in mind, employing such proteins or the probiotic strain itself to battle Salmonella biofilms in the food industry is a plausible ambition. Woo and Ahn (2013) discussed competitive exclusion in the context of probiotic mediated exclusion and displacement against biofilm formation of L. monocytogenes and S. Typhimurium. From milk tanks and milking equipment in two traditional Algerian farms, a Lactobacillus pentosus strain was isolated that had strong activity against the adhesion of $S$. aureus cells to polystyrene and stainless steel (Ait Ouali et al., 2014). Additionally, this L. pentosus LB3F2 (among other LABs isolated) formed biofilms on the industrially relevant surfaces tested, highlighting its potential for use in food processing as a beneficial biofilm former capable of inhibiting $S$. aureus by creating a protective barrier on equipment surfaces and/or via competitive exclusion of the pathogen. In the cases of competitive exclusion and beneficial bacteria with barrier functions it must be considered nonetheless that there is potential for the protective strain to develop resistance to the sanitizer/disinfectant used in cleaning protocols and there exists the possibility of transference of the resistant plasmid to the spoilage/pathogenic strain that it is protecting against.

\section{Naturally Sourced}

Extracts from aromatic plants are being investigated as natural agents against bacterial biofilms (Bridier et al., 2015). They are generally regarded as safe (GRAS) and so are compatible with current regulations regarding food production. Examples include: oregano oil, thymol and carvacrol effective against Staphylococcus biofilms (Nostro et al., 2007). Thymus vulgare essential oil caused a $90 \%$ reduction in $\mathrm{AHL}$ production (measured by quantifying violacein production in the AI-1 QS indicator strain Chromobacterium violaceum CV026) of P. fluorescens KM121 in a 72 h old culture (Myszka et al., 2016). These results were confirmed by liquid chromatography mass spectrometry (LC-MS). The essential oil also strongly inhibited cell adhesion to stainless steel, viewed by fluorescence microcopy and inhibition of adhesion quantified by the scale described by Le Thi et al. (2001). The results showed P. fluorescens KM121 first degree adhesion to be dominant on the stainless steel coupons, meaning that on 50 randomly selected visual fields only $0-5$ bacterial cells were present post-washing. Extracted from Euodia ruticarpa (a plant in the Rutaceae family), the compounds evodiamine and rutaecarpine and a quinolinone fraction were found to reduce biofilm formation of C. jejuni NCTC 11168 on stainless steel after $24 \mathrm{~h}$ or more (Bezek et al., 2016). In a recent study, B. subtilis biofilms formed on polystyrene microtitre plates and stainless steel coupons were treated with 1 and $2 \%$ solutions of organic acids (citric, malic, and gallic) isolated from natural sources and additionally chlorine for comparison. Akbas and Cag (2016) reported citric acid as being as effective at biofilm inhibition and disruption as the chlorine standard, results which may encourage exploration of organic acids as a potential natural alternative to chemical substances for Bacillus biofilm control. Maderova et al. (2016) employed an unusual method for the control of $P$. aeruginosa biofilms in a water environment by utilizing food waste materials as QS signaling molecule adsorbents. These authors were successful in reporting reduced biofilm formation (without consequence to cell viability) through the addition of spent grain. Magnetic modification of promising food materials, including the grain, allowed for their separation and removal from the water environment. Following the success of this study, the addition (and subsequent removal afterward) of food materials spoiled by 'safe, food grade microbes to certain food processing arrangements could be a possible avenue of research for biofilm control in the food industry.

\section{Quorum Sensing Inhibitors}

Strategies that target quorum sensing and, therefore, biofilm formation (and other virulence factors) as opposed to bactericidal strategies exert less selection pressure to develop resistance to the inhibitory agent. In these instances, bacteria can be 'controlled' in place of being killed. Many organisms produce quorum quenching (QQ) molecules when competing with neighboring species for nutrients, space, etc. QQ refers to the inhibition of QS through degradation and/or inactivation of the QS signaling molecules (Dong et al., 2001). The inability of the susceptible bacterial cell to sense and respond to its population density interferes with various secondary cell functions, usually 
diminishing some aspect of virulence. P. aeruginosa metabolizes its own AHL signaling molecules by cleaving QS molecules to form a homoserine or a fatty acid which it consumes as carbon and nitrogen sources (Huang et al., 2003). Signaling molecules are also degraded by the producer to maintain appropriate signal concentration and to prevent improper activation of the QS system. Agrobacterium tumefaciens degrades its own QS signaling molecules to terminate QS activities by producing the AHLlactonase AttM while in its stationary phase of growth (Zhang et al., 2002). The concept of QQ as an anti-biofilm tool lies with the addition of the isolated inhibitory molecule (or the producer itself) as a bioagent in the food industry or its formulation into an antibacterial treatment for clinical use against human pathogens (see Figure 3). Strategies employed to prevent biofilm formation targeting the QS system are based on inhibition of cell-to-cell communication, which can be executed in a number of ways, including the inhibition of signaling peptides synthesis or the degradation of the peptides, prevention of signaling peptidereceptor binding or inhibition of the signal transduction cascade further down the line (Brackman and Coenye, 2015). Although a great deal of further study is still required to fully understand the relationship between QS and biofilm formation, it is accepted that QS inhibition is a promising strategy to combat bacterial biofilms. Viana et al. (2009) investigated the role of AHLs in biofilm formation by $H$. alvei, a bacterial food contaminant commonly isolated from raw milk (Ercolini et al., 2009) and cheeses (Coton et al., 2012). Despite H. alvei being considered to be an opportunistic human pathogen in some nosocomial infections (Rodríguez-Guardado et al., 2005), the bacterium is often added to certain cheeses to improve taste and aid in ripening and so is considered to be a microorganism with beneficial technological properties for use in food fermentation (Bourdichon et al., 2012). Previous studies (Pinto et al., 2007) have established that $H$. alvei is a producer of AHLs and so the group set out to detect the presence of AHLs in a $H$. alvei biofilm with the objective of establishing a link between QS and biofilm formation. On verifying the presence of AHLs in the biofilm, they also demonstrated the inhibition of biofilm formation by synthetic furanones (previously shown by Manefield et al., 2002). It was also established that $H$. alvei hall, an AHL-synthase gene mutant, was deficient in proper biofilm formation, further strengthening the hypothesis that AHL-mediated QS plays a role in biofilm formation by $H$. alvei. In a study carried out by Van Houdt et al. (2004) in vitro biofilm formation was characterized in 68 Gram-negative bacterial strains isolated from a raw vegetable processing line. Accompanying assays using reporter bacteria detected the presence of QS signals produced by each strain. Although, five isolates were determined to produce AHLs and AI-2 signals and a further 26 strains were AI-2 producers, a general correlation between the QS signals detected and measurable biofilm formation was not clear for the strains under investigation. Nevertheless, the authors stipulated that the absence of a link between QS and biofilm formation in their study does not dismiss the influence of signaling molecules in other biofilm formers. Another study highlighted the link between QS and biofilm formation in reporting that $P$. aeruginosa lasI mutant strains that were unable to synthesize the AHL 3-oxo-C12-HSL formed atypical biofilms when cultured in a flow cell (Bjarnsholt et al., 2010). The antibiotic azithromycin was used successfully as a QS blocking agent against the AHLs C4-HSL and 3-oxo-C12-HSL in P. aeruginosa and in doing so impacted bacterial biofilm formation by reducing cell adhesion to polystyrene surfaces (Favre-Bonte et al., 2003). Tan et al. (2014) carried out a long term study investigating the role of QS signaling molecules in multi-species microbial communities undergoing granulation through incubation of a mixed bacterial culture in a bioreactor used for water treatment. Simultaneously, they assessed the concentration levels of AHL molecules present at different stages of granule formation. The group found that AHL concentration positively correlated with the behavioral steps involved in granulation and that addition of exogenous AHLs to the culture resulted in increased EPS production, suggesting a role for QS signaling in bacterial granule formation. A later study performed by the same group (Tan et al., 2015) demonstrated
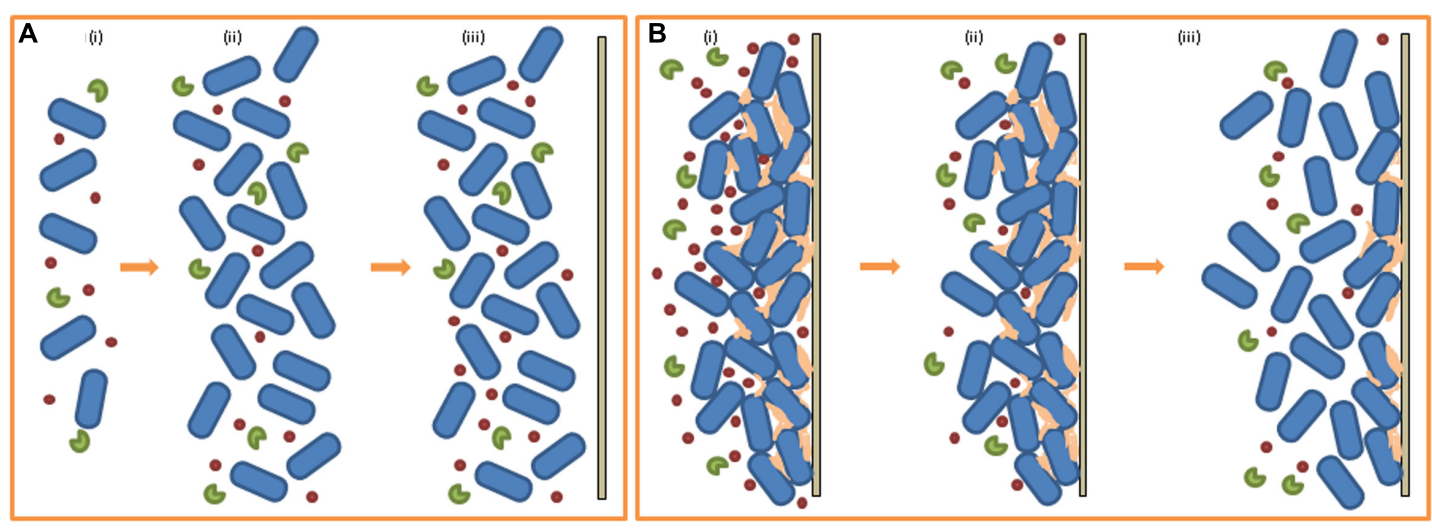

FIGURE 3 | Quorum quenching (QQ) and biofilm formation. (A) Effect of QQ molecules on early stage biofilm formation (i) low population density, low QS signal, addition of QQ molecules (ii) high population density, low QS signal, QS molecules degraded by QQs (iii) absence of attachment to solid surface, biofilm formation does not occur. (B) Effect of QQ molecules on early pre-existing biofilm (i) biofilm formed, high QS signal, addition of QQ molecules (ii) QS molecules degraded by QQs, reduction of QS signal (iii) decrease in EPS production, release of cells, return of released cells to planktonic state (i.e., reduced biofilm). 
that QQ was the primary mode (as opposed to environmental factors) of QS signal reduction and served as a key player in the regulation of different stages of bacterial granulation formation.

Due to the apparent benefits of inhibiting QS, studies screening large libraries/collections of microorganisms in the search for QQ molecule producers have recently emerged. Christiaen et al. (2011) employed a high-throughput approach to screening environmental samples cultivated in minimal media supplemented with AHLs as their sole sources of carbon and nitrogen. These enriched isolates were screened using the QS inhibition selector biosensor strain $P$. aeruginosa QSIS2 (assay developed by Rasmussen et al., 2005), which revealed 41 isolates with QQ activity (in some cases resistant to heat and proteinase $\mathrm{K}$ treatments). Kusari et al. (2014) showed that environmentally derived samples of the endophytic bacteria of the plant Cannabis satvia $\mathrm{L}$. were capable of quenching four different AHL molecules of the biosensor strain $C$. violaceum which regulates production of the purple pigment violacein through QS signaling activity. Large numbers of diverse unculturable bacteria from environmental samples may also be efficiently screened for QQ activity through the construction and scanning of metagenomic libraries (Coughlan et al., 2015). For example a functional metagenomic library assembled from soil samples was screened using a QQ biosensor assay employing A. tumefaciens NTL4 as an indicator microorganism and in doing so identified three active clones (including two novel lactonases) capable of reducing motility and biofilm formation in P. aeruginosa (Schipper et al., 2009). Studies describing the identification of quorum quenching molecules are briefly summarized in Table 1.

Quorum quenching activity is predominantly due to the action of certain enzymes that degrade QS molecules such as AHLs. It is thought that there are four potential cleavage sites in AHL QS molecules for cutting by enzymes (Chen et al., 2013). Two microbial enzyme families exist that are capable of cleaving AHL structures. Class I includes lactonases, acylases and paraoxonases. Lactonases or decarboxylases catalyze the degradation of the homoserine lactone ring. Dong et al. (2000) initially reported the AHL-degrading activity of a lactonase encoded by a gene (aiiA) cloned from Bacillus spp. $240 \mathrm{~B}$ through cleavage of the lactone ring from the acyl moiety, which inhibited virulent activity of the plant pathogen Erwinia carotovora. The AidH AHL-lactonase from Ochrobactrum spp., which hydrolyzes the ester bond of the homoserine lactone ring of AHLs, has a very broad range of targets and is effective at reducing biofilm formation of the food spoilage bacterial strain P. fluorescens 2P24 (Mei et al., 2010). AiiA $A_{B 546}$ AHL-lactonase from Bacillus spp. B546 displayed a broad range of AHL substrate specificity and showed promise for use in reducing fish mortality by controlling the pathogen Aeromonas hydrophila (Chen et al., 2010). Cao et al. (2012) reported the oral administration of a broad-spectrum, thermostable and protease resistant $\mathrm{AiiA}_{\mathrm{AI} 96}$ AHL-lactonase from Bacillus spp. AI96 to be successful in the attenuation of $A$. hydrophila infection in zebrafish. In another study, three bacterial strains with QQ activity were isolated from the rhizosphere of ginger (Zingiber officinale) from the Malaysian rainforest. The strains belonging to the genera Acinetobacter and Klebsiella possessed broad spectrum lactonase activity while the Burkholderia strain was capable of reduction of 3-oxo-AHLs to 3-hydroxy compounds, thus inactivating the AHL signaling molecules. All three strains were found to attenuate virulence of P. aeruginosa and E. carotovora in co-culture assays (Chan et al., 2011).

Acylases or deaminases cleave an AHL into a homoserine lactone ring and a free fatty acid moiety through hydrolysis of their amide link (Lin et al., 2003). AHL-acylases generally show higher substrate specificity than lactonases for AHL molecules based on the length of their acyl side chains. AHL-acylase AiiD has a higher affiliation for the degradation of long chain AHLs. Cloning of the aiiD gene from Ralstonia strain XJ12B into $P$. aeruginosa resulted in inhibition of AHL 3-oxo-C10HSL accumulation and interference with some QS related traits (Lin et al., 2003). Genes encoding acylases capable of degrading the primary QS signaling molecules of $P$. aeruginosa exist within the $P$. aeruginosa $\mathrm{PAO} 1$ genome itself. quiP and $p v d Q$ encode acylases which specifically degrade 3-oxo-C12HSL and AHLs with long acyl chains only, excluding those with short acyl chains (Sio et al., 2006). An additional AHL acylase in the $P$. aeruginosa PAO1 genome was reported by Wahjudi et al. (2011). The pa0305 gene, predicted to encode a penicillin acylase, was cloned and its functional protein PA0305 characterized. The protein was shown to degrade AHLs with acyl side chains of 6-14 carbons in length and its overexpression reduced both accumulation of the QS signaling molecule 3-oxo-C12-HSL and virulence of $P$. aeruginosa. Morohoshi et al. (2008) showed that expression of the aac gene from Shewanella spp. strain MIB015 in the fish pathogen Vibrio anguillarum, which is known to produce three distinct AHL signaling molecules and to regulate biofilm formation through QS (Croxatto et al., 2002), resulted in reduced biofilm formation on a polypropylene plastic surface. An AHL-degrading bacterial strain was isolated from a sea water sample collected in Malacca, Malaysia (Wong et al., 2012a). This strain, which contained genes with high homology to known acylases, was capable of utilizing $N$-(3-oxohexanoyl)-L-homoserine lactone as its sole carbon source and degrading AHLs with and without 3-oxo group substitution at the $\mathrm{C} 3$ position in the acyl side chain. The strain was also observed to release AHLs (detected in the supernatant) indicating both QS and QQ activity. This group also isolated a strain with similar activity and phylogenetic roots from tropical wetland water also in Malacca (Wong et al., 2012b).

Another type of QQ enzyme is the lactonase-like paraoxonases isolated from mammalian sera. Enzymes isolated from mammalian sera were reported to be capable of hydrolyzing the lactone ring of AHLs produced by $P$. aeruginosa (Yang et al., 2005). Other examples of anti-QS agents isolated from eukaryotes include two lactonases isolated from a collection of root-associated fungi (Uroz and Heinonsalo, 2008) and various quorum quenchers derived from plants (reviewed by Koh et al., 2013). Class II microbial AHL-targeting enzymes are oxidoreductases which target the acyl side chain 
TABLE 1 | Studies describing quorum quenching molecules.

\begin{tabular}{|c|c|c|c|c|}
\hline QQ molecule/activity & $\begin{array}{l}\text { Producing spp./closest } \\
\text { known relatives }\end{array}$ & Environment sampled & Attenuated virulence of: & Reference \\
\hline Plant extracts & $\begin{array}{l}\text { Conocarpus erectus, } \\
\text { Chamaesyce hypericifolia, } \\
\text { Callistemon viminalis, Bucida } \\
\text { buceras, Tetrazygia bicolor, and } \\
\text { Quercus virginiana }\end{array}$ & $\begin{array}{l}\text { Extracts of six South Florida } \\
\text { plants }\end{array}$ & $\begin{array}{l}\text { Pseudomonas aeruginosa } \\
\text { PAO1 (biofilm reduction) }\end{array}$ & $\begin{array}{l}\text { Adonizio et al., } \\
2008\end{array}$ \\
\hline $\begin{array}{l}\text { Broad spectrum lactonase } \\
\text { activity }\end{array}$ & $\begin{array}{l}\text { Genera Acinetobacter, } \\
\text { Klebsiella, and Burkholderia }\end{array}$ & $\begin{array}{l}\text { Rhizosphere of ginger (Zingiber } \\
\text { officinale), Rimba IImu, } \\
\text { University of Malaya, Malaysia }\end{array}$ & $\begin{array}{l}\text { P. aeruginosa PAO1, Erwinia } \\
\text { carotovora strain GS101 and } \\
\text { PNP22 }\end{array}$ & Chan et al., 2011 \\
\hline $\begin{array}{l}\text { Lactonase (AiiA } A_{B 546} \text { expressed } \\
\text { in Pichia pastoris GS115) }\end{array}$ & Bacillus spp. B546 & $\begin{array}{l}\text { Mud of a fish Pond, Wuqing, } \\
\text { Tianjin, China }\end{array}$ & $\begin{array}{l}\text { Aeromonas hydrophila ATCC } \\
7966\end{array}$ & Chen et al., 2010 \\
\hline Furocoumarins, grapefruit juice & $\mathrm{N} / \mathrm{A}$ & Grapefruit and grapefruit juice & $\begin{array}{l}\text { Escherichia coli O157:H7, } \\
\text { Salmonella Typhimurium and } \\
\text { P. aeruginosa (biofilm reduction } \\
\text { in all three) }\end{array}$ & $\begin{array}{l}\text { Girennavar et al., } \\
2008\end{array}$ \\
\hline $\begin{array}{l}\text { Acylase } \\
\text { Lactonase }\end{array}$ & $\begin{array}{l}\text { P. aeruginosa } \\
\text { PAO1 } \\
\text { Pseudomonas strain PAI-A }\end{array}$ & $\begin{array}{l}\text { N/A } \\
\text { Soil }\end{array}$ & $\begin{array}{l}\text { Both utilized own AHLs as } \\
\text { carbon/nitrogen sources }\end{array}$ & Huang et al., 2003 \\
\hline Lactonase & Rhizobium spp. strain NGR234 & N/A & $\begin{array}{l}P . \text { aeruginosa } \mathrm{PAO} 1 \text { (including } \\
\text { biofilm reduction) }\end{array}$ & $\begin{array}{l}\text { Krysciak et al., } \\
2011\end{array}$ \\
\hline $\begin{array}{l}\text { Acylase (aiiD expressed in } \\
P \text {. aeruginosa) }\end{array}$ & Ralstonia strain XJ12B & $\begin{array}{l}\text { Biofilm in experimental water } \\
\text { treatment system, The National } \\
\text { University of Singapore }\end{array}$ & $P$. aeruginosa $\mathrm{PAO} 1$ & Lin et al., 2003 \\
\hline Lactonase (ah/S) & Solibacillus silvestris StLB046 & Leaf surface of the potato & $\begin{array}{l}\text { P. carotovorum subsp. } \\
\text { carotovorum }\end{array}$ & $\begin{array}{l}\text { Morohoshi et al., } \\
2012\end{array}$ \\
\hline $\begin{array}{l}\text { Essential oils } \\
\text { thymol, } \\
\text { carvacrol, eugenol }\end{array}$ & N/A & $\begin{array}{l}\text { Sigma-Aldrich Chemicals (St. } \\
\text { Louis, MO, USA) }\end{array}$ & $\begin{array}{l}\text { Effective against paper } \\
\text { mill-associated biofilms }\end{array}$ & Neyret et al., 2014 \\
\hline $\begin{array}{l}\text { Essential oils } \\
\text { oregano (Origanum vulgare L.) } \\
\text { oil, carvacrol, thymol }\end{array}$ & $\begin{array}{l}\text { Origanum vulgare } \mathrm{L} \text {. } \\
\text { N/A } \\
\text { N/A }\end{array}$ & Ocular infections & $\begin{array}{l}\text { Staphylococcus aureus, } \\
\text { Staphylococcus epidermidis } \\
\text { (biofilm reduction) }\end{array}$ & Nostro et al., 2007 \\
\hline $\begin{array}{l}\text { Two novel lactonases, one } \\
\text { known lactonase }\end{array}$ & $\begin{array}{l}\text { Nitrobacter spp. Strain } \\
\text { Nb-311A, P. fluorescens, } \\
\text { Xanthomonas campestris }\end{array}$ & $\begin{array}{l}\text { Soil functional metagenomic } \\
\text { library }\end{array}$ & P. aeruginosa (biofilm reduction) & $\begin{array}{l}\text { Schipper et al., } \\
2009\end{array}$ \\
\hline Acylase (PA2385) & $\begin{array}{l}\text { Purified from } P \text {. aeruginosa } \\
\text { PAO1 }\end{array}$ & Holloway collection & $P$. aeruginosa $\mathrm{PAO} 1$ & Sio et al., 2006 \\
\hline Two lactonases & $\begin{array}{l}\text { Phialocephala fortinii, } \\
\text { Ascomycete isolate, } \\
\text { Meliniomyces variabilis and a } \\
\text { potential mycorrhizal isolate }\end{array}$ & $\begin{array}{l}16 \text { isolates of mycorrhizal and } \\
\text { non-mycorrhizal } \\
\text { root-associated fungi }\end{array}$ & N/A & $\begin{array}{l}\text { Uroz and } \\
\text { Heinonsalo, } 2008\end{array}$ \\
\hline
\end{tabular}


TABLE 1 | Continued

\begin{tabular}{|c|c|c|c|c|}
\hline QQ molecule/activity & $\begin{array}{l}\text { Producing spp./closest } \\
\text { known relatives }\end{array}$ & Environment sampled & Attenuated virulence of: & Reference \\
\hline Amidolytic activity & Comamonas spp. strain D1 & Soil & P. carotovorum strain GS101 & Uroz et al., 2007 \\
\hline Novel lactonase (qsdA) & $\begin{array}{l}\text { Rhodococcus erythropolis } \\
\text { strain W2 }\end{array}$ & $\mathrm{N} / \mathrm{A}$ & $\mathrm{N} / \mathrm{A}$ & Uroz et al., 2008 \\
\hline $\begin{array}{l}\text { Acylase (PA0305 expressed in } \\
\text { E. coli and P. aeruginosa) }\end{array}$ & $\begin{array}{l}\text { Purified from } P \text {. aeruginosa } \\
\text { PAO1 }\end{array}$ & $\mathrm{N} / \mathrm{A}$ & $P$. aeruginosa $\mathrm{PAO} 1$ & Wahjudi et al., 2011 \\
\hline Novel lactonase (AiiM protein) & M. testaceum StLB037 & Leaf surface of the potato & $\begin{array}{l}\text { P. carotovorum subsp. } \\
\text { carotovorum }\end{array}$ & Wang et al., 2010 \\
\hline Acylase activity & $P$. aeruginosa strain MW3A & $\begin{array}{l}\text { Subsurface seawater, Malacca, } \\
\text { Malaysia }\end{array}$ & $\mathrm{N} / \mathrm{A}$ & Wong et al., 2012a \\
\hline Acylase activity & P. aeruginosa strain 2SW8 & $\begin{array}{l}\text { Tropical wetland water, } \\
\text { Malaysia }\end{array}$ & $\mathrm{N} / \mathrm{A}$ & Wong et al., 2012b \\
\hline Lactonase-like paraoxonase & N/A & Serum of six mammalian spp. & $\begin{array}{l}\text { Hydrolysis of } \\
\text { P. aeruginosa-specific AHLS }\end{array}$ & Yang et al., 2005 \\
\hline $\begin{array}{l}\text { Lactonase (aiiA expressed in } \\
\text { E. coli) }\end{array}$ & $\begin{array}{l}\text { Bacillus amyloliquefaciens } \\
\text { strain PEBA20 }\end{array}$ & Laboratory collection strain & $\begin{array}{l}\text { P. carotovorum subsp. } \\
\text { carotovorum }\end{array}$ & Yin et al., 2010 \\
\hline
\end{tabular}

of AHL molecules and catalyze a modification of the chemical structure of the signal, that is not degraded (Chen et al., 2013). A novel oxidoreductase identified from a metagenomic library reduced pyocyanin production, motility and biofilm formation when expressed in $P$. aeruginosa PAO1 (Bijtenhoorn et al., 2011).

AI-2 QS signaling systems may also be potential antibiofilm targets. As previously mentioned, luxS influences biofilm formation in L. monocytogenes (Sela et al., 2006). Potential blockers of AI-2 signal synthesis have been investigated by Zhao et al. (2003) and Alfaro et al. (2004) with the successful design of synthetic AI-2 inhibitors reported by Shen et al. (2006) that act as competitive inhibitors of the LuxS protein interfering with the synthesis of AI-2 precursors. Recently, from a functional metagenomic library, Weiland-Bräuer et al. (2016) reported the identification of a clone originating from a German Salt Marsh to be effective at prevention of biofilm formation in Klebsiella oxytoca $\mathrm{M} 5 \mathrm{a} 1$ and $K$. pneumoniae isolated from patients with urinary tract infections, species with reported AI-2 mediated QS (Balestrino et al., 2005; Zhu et al., 2011). The purified protein was suspected to possess oxidoreductase activity. To date, the AIP system in Gram-positive bacteria has not been examined as a target for potential biofilm inhibition but it may prove to be a promising route for future study.

As discussed above, the isolation of anti-biofilm agents from nature is an attractive prospect, leading to the search for quorum quenchers from organic sources. Girennavar et al. (2008) reported QS inhibition in V. harveyi biosensor strain by grapefruit juice and bioactive extracts from grapefruits. Additionally, they were also found to be capable of inhibition of biofilm formation by E. coli O157:H7, S. Typhimurium and $P$. aeruginosa, species which often prove troublesome for the food industry. In another study, extracts from six South Florida plants were effective in impacting QS signaling in $P$. aeruginosa with significantly reduced biofilm formation observed in the presence of extracts from three of these plants (Adonizio et al., 2008).

\section{CONCLUSION AND FUTURE PROSPECTS/DIRECTIONS}

The majority of bacteria, including those detected in food processing environments, are gifted with the ability to resist standard cleaning measures by their capacity to form biofilms on many of the surfaces approved for use in the food industry. This persistence leads to increased microbial load in both the food processing environments and in the subsequent food products, leading to food spoilage and reduced shelf life and also to increased risk of infectious outbreaks originating from food sources. Food safety is a global concern and increased risk of infection is accompanied by a requirement for more stringent and frequent evaluation of food manufacture and processing plants. Economic losses suffered by food production facilities and health related costs faced during foodborne pathogen epidemics mean that the presence of biofilm-forming bacteria can have a considerable impact on food processing establishments and, so, impeding their ability to persist in these environments is a very attractive objective for both food industry workers and researchers.

Current strategies show promise in laboratory-based experiments, with the successful inhibition of biofilm formation reported in numerous studies. However, there are considerations when applying these approaches to real life situations that limit their value to the food industry. Firstly, it is important that anti-biofilm agents used in food processing facilities meet safety requirements outlined by appropriate regulatory bodies. Agents deemed successful in the lab must also be tested and proven safe for application to food contact surfaces and, especially, if such agents are to be added to the food product itself. Ideally, quorum quenchers derived from food-grade microorganisms, plants and other natural sources would be most suitable. Additionally, researchers developing anti-biofilm strategies must acknowledge that product quality is a top priority for food manufacturers, and so, biofilm inhibitors must not influence the taste, texture or palatability of the food in any way. This is especially relevant 
to the dairy industry, where many fermented milk products are developed using specific populations of microorganisms in a carefully refined system that is sensitive to change. Here, strategies that target QS signaling over growth inhibitors or bactericidal agents are useful as they do not threaten the lives of useful bacteria in the process. In such cases, the specificity of the quorum quencher is significant so as not to inhibit QS signals of beneficial bacteria that may regulate certain factors responsible for their fermentation abilities and perhaps the production of particular by-products that lend aromas and textures to the finished food. Searching for quorum quenchers from the food processing environment itself may prove useful here as competition among microbes occupying the same niche leads to the production of compounds, such as bacteriocins and QS inhibitors, specific to their common competitors. This approach may increase the likelihood of discovering quorum quenchers with action specific against the target bacteria. Another necessary factor to consider when introducing a lab-derived method to an industrial setting is the practicality of the biofilm-fighting strategy proposed. Notably with QS inhibitors, being derived from living organisms and often vulnerable to harsh climates, the active bioagents must be capable of withstanding conditions typical of food processing environments. Heat stability as well as activity at low temperatures, a broad $\mathrm{pH}$ range of action

\section{REFERENCES}

Abee, T., Kovács, Á. T., Kuipers, O. P., and van der Veen, S. (2011). Biofilm formation and dispersal in Gram-positive bacteria. Curr. Opin. Biotechnol. 22, 172-179. doi: 10.1016/j.copbio.2010.10.016

Adonizio, A., Kong, K.-F., and Mathee, K. (2008). Inhibition of quorum sensingcontrolled virulence factor production in Pseudomonas aeruginosa by South Florida plant extracts. Antimicrob. Agents Chemother. 52, 198-203. doi: 10.1128/AAC.00612-07

Ait Ouali, F., Al Kassaa, I., Cudennec, B., Abdallah, M., Bendali, F., Sadoun, D., et al (2014). Identification of lactobacilli with inhibitory effect on biofilm formation by pathogenic bacteria on stainless steel surfaces. Int. J. Food Microbiol. 191, 116-124. doi: 10.1016/j.ijfoodmicro.2014.09.011

Akbas, M. Y., and Cag, S. (2016). Use of organic acids for prevention and removal of Bacillus subtilis biofilms on food contact surfaces. Food Sci. Technol. Int. 22, 587-597. doi: 10.1177/1082013216633545

Al-Adawi, A. S., Gaylarde, C. C., Sunner, J., and Beech, I. B. (2016). Transfer of bacteria between stainless steel and chicken meat: a CLSM and DGGE study of biofilms. AIMS Microbiol. 2, 340-358. doi: 10.3934/microbiol.2016. 3.340

Alfaro, J. F., Zhang, T., Wynn, D. P., Karschner, E. L., and Zhou, Z. S. (2004). Synthesis of LuxS inhibitors targeting bacterial cell-cell communication. Org. Lett. 6, 3043-3046. doi: 10.1021/ol049182i

Annonymous (1997). Chemical Disinfectants and Antiseptics - Quantitative Suspension Test for the Evaluation of Bactericidal Activity of Chemical Disinfectants and Antiseptics used in Food. Industrial, Domestic and Institutional Areas - Test Method and Requirements (Phase 2/Step1). EN 1276. Londn: British Standards Institution.

Antoniouand, K., and Frank, J. F. (2005). Removal of Pseudomonas putida biofilm and associated extracellular polymeric substances from stainless steel by alkali cleaning. J. Food Prot. 68, 277-281.

Augustin, M., Ali-Vehmas, T., and Atroshi, F. (2004). Assessment of enzymatic cleaning agents and disinfectants against bacterial biofilms. J. Pharm. Pharm. Sci. 7, 55-64.

Bai, A. J., and Rai, V. R. (2011). Bacterial quorum sensing and food industry. Compr. Rev. Food Sci. Food Saf. 10, 183-193. doi: 10.1111/j.15414337.2011.00150.x and resistance to proteases are all attractive qualities in a food-grade quorum quencher, depending on the process in question.

Quorum quenching has been shown to be a promising avenue of anti-biofilm research in food microbiology, with limitations faced in the transferal of laboratory findings to industrial applications. As discussed above, the criteria outlining a suitable QS inhibitor for inhibition of biofilm in the food industry is a detailed and extensive list. The search continues, employing a number of screening techniques on samples from exotic and domestic sources alike.

\section{AUTHOR CONTRIBUTIONS}

LC, PC, $\mathrm{CH}$, and AA-O designed the manuscript; LC and AA-O wrote the manuscript; $\mathrm{PC}$ and $\mathrm{CH}$ critically revised the manuscript.

\section{ACKNOWLEDGMENT}

The financial support of Science Foundation Ireland (SFI) under Grant Number 13/SIRG/2157 is acknowledged.

Balestrino, D., Haagensen, J. A. J., Rich, C., and Forestier, C. (2005). Characterization of type 2 quorum sensing in Klebsiella pneumoniae and relationship with biofilm formation. J. Bacteriol. 187, 2870-2880. doi: 10.1128/JB.187.8.2870-2880.2005

Banat, I. M., Franzetti, A., Gandolfi, I., Bestetti, G., Martinotti, M. G., Fracchia, L., et al. (2010). Microbial biosurfactants production, applications and future potential. Appl. Microbiol. Biotechnol. 87, 427-444. doi: 10.1007/s00253-0102589-0

Bassler, B. L., Wright, M., Showalter, R. E., and Silverman, M. R. (1993). Intercellular signalling in Vibrio harveyi: sequence and function of genes regulating expression of luminescence. Mol. Microbiol. 9, 773-786. doi: 10.1111/j.1365-2958.1993.tb01737.x

Baumann, A. R., Martin, S. E., and Feng, H. (2009). Removal of Listeria monocytogenes biofilms from stainless steel by use of ultrasound and ozone. J. Food Prot. 72, 1306-1309.

Bezek, K., Kurinčič, M., Knauder, E., Klančnik, A., Raspor, P., Bucar, F., et al. (2016). Attenuation of adhesion, biofilm formation and quorum sensing of Campylobacter jejuni by Euodia ruticarpa. Phytother. Res. 30, 1527-1532. doi: $10.1002 /$ ptr.5658

Bijtenhoorn, P., Mayerhofer, H., Müller-Dieckmann, J., Utpatel, C., Schipper, C., Hornung, C., et al. (2011). A novel metagenomic shortchain dehydrogenase/reductase attenuates Pseudomonas aeruginosa biofilm formation and virulence on Caenorhabditis elegans. PLoS ONE 6:e26278. doi: 10.1371/journal.pone.0026278

Bjarnsholt, T., Tolker-Nielsen, T., Hoiby, N., and Givskov, M. (2010). Interference of Pseudomonas aeruginosa signalling and biofilm formation for infection control. Expert Rev. Mol. Med. 12:e11. doi: 10.1017/S1462399410001420

Bourdichon, F., Casaregola, S., Farrokh, C., Frisvad, J. C., Gerds, M. L., Hammes, W. P., et al. (2012). Food fermentations: microorganisms with technological beneficial use. Int. J. Food Microbiol. 154, 87-97. doi: 10.1016/j.ijfoodmicro.2011.12.030

Brackman, G., and Coenye, T. (2015). Quorum sensing inhibitors as anti-biofilm agents. Curr. Pharm. Des. 21, 5-11. doi: 10.2174/1381612820666140905114627

Bremer, P. J., Fillery, S., and McQuillan, A. J. (2006). Laboratory scale Clean-InPlace (CIP) studies on the effectiveness of different caustic and acid wash steps on the removal of dairy biofilms. Int. J. Food Microbiol. 106., 254-262. doi: 10.1016/j.ijfoodmicro.2005.07.004 
Briandet, R., Lacroix-Gueu, P., Renault, M., Lecart, S., Meylheuc, T., Bidnenko, E., et al. (2008). Fluorescence correlation spectroscopy to study diffusion and reaction of bacteriophages inside biofilms. Appl. Environ. Microbiol. 74, 21352143. doi: 10.1128/AEM.02304-07

Bridier, A., Sanchez-Vizuete, P., Guilbaud, M., Piard, J. C., Naitali, M., and Briandet, R. (2015). Biofilm-associated persistence of food-borne pathogens. Food Microbiol. 45, 167-178. doi: 10.1016/J.Fm.2014.04.015

Brown, H. L., Hanman, K., Reuter, M., Betts, R. P., and Van Vliet, A. H. M. (2015). Campylobacter jejuni biofilms contain extracellular DNA and are sensitive to DNase I treatment. Front. Microbiol. 6: 699. doi: 10.3389/fmicb.2015. 00699

Brown, H. L., Reuter, M., Salt, L. J., Cross, K. L., Betts, R. P., and van Vliet, A. H. M. (2014). Chicken juice enhances surface attachment and biofilm formation of Campylobacter jejuni. Appl. Environ. Microbiol. 80, 7053-7060. doi: 10.1128/AEM.02614-14

Bruhn, J. B., Christensen, A. B., Flodgaard, L. R., Nielsen, K. F., Larsen, T. O., Givskov, M., et al. (2004). Presence of acylated homoserine lactones (AHLs) and AHL-producing bacteria in meat and potential role of AHL in spoilage of meat. Appl. Environ. Microbiol. 70, 4293-4302. doi: 10.1128/AEM.70.7.42934302.2004

Buckenhüskes, H. J. (1993). Selection criteria for lactic acid bacteria to be used as starter cultures for various food commodities. FEMS Microbiol. Rev. 12, 253-271. doi: 10.1016/j.meatsci.2006.10.022

Burmølle, M., Webb, J. S., Rao, D., Hansen, L. H., Sørensen, S. J., and Kjelleberg, S. (2006). Enhanced biofilm formation and increased resistance to antimicrobial agents and bacterial invasion are caused by synergistic interactions in multispecies biofilms. Appl. Environ. Microbiol. 72, 3916-3923. doi: 10.1128/aem.03022-05

Cabeça, T. K., Pizzolitto, A. C., and Pizzolitto, E. L. (2012). Activity of disinfectants against foodborne pathogens in suspension and adhered to stainless steel surfaces. Braz. J. Microbiol. 43, 1112-1119. doi: 10.1590/S1517838220120003000038

Cao, Y., He, S., Zhou, Z., Zhang, M., Mao, W., Zhang, H., et al. (2012). Orally administered thermostable N-Acyl homoserine lactonase from Bacillus sp. strain AI96 attenuates Aeromonas hydrophila infection in zebrafish. Appl. Environ. Microbiol. 78, 1899-1908. doi: 10.1128/AEM. 06139-11

Cappello, S., and Guglielmino, S. P. P. (2006). Effects of growth temperature on polystyrene adhesion of Pseudomonas aeruginosa ATCC 27853. Braz. J. Microbiol. 37, 205-207. doi: 10.1590/S1517-83822006000300001

Carpentier, B., and Cerf, O. (1993). Biofilms and their consequences, with particular reference to hygiene in the food industry. J. Appl. Bacteriol. 75., 499-511. doi: 10.1111/j.1365-2672.1993.tb01587.x

Champomier-Verges, M. C., Chaillou, S., Cornet, M., and Zagorec, M. (2001). Lactobacillus sakei: recent developments and future prospects. Res. Microbiol. 152, 839-848. doi: 10.1016/S0923-2508(01)01267-0

Chan, K. G., Atkinson, S., Mathee, K., Sam, C. K., Chhabra, S. R., Camara, M., et al. (2011). Characterization of $\mathrm{N}$-acylhomoserine lactone-degrading bacteria associated with the Zingiber officinale (ginger) rhizosphere: co-existence of quorum quenching and quorum sensing in Acinetobacter and Burkholderia. BMC Microbiol. 11:51. doi: 10.1186/1471-2180-11-51

Characklis, W. G., and Marshall, K. C. (eds). (1990). "Biofilm processes," in Biofilms, New York, NY: John Wiley \& Sons, 195-231.

Chen, F., Gao, Y., Chen, X., Yu, Z., and Li, X. (2013). Quorum quenching enzymes and their application in degrading signal molecules to block quorum sensing-dependent infection. Int. J. Mol. Sci. 14, 17477-17500. doi: 10.3390/ijms140917477

Chen, R., Zhou, Z., Cao, Y., Bai, Y., and Yao, B. (2010). High yield expression of an AHL-lactonase from Bacillus sp. B546 in Pichia pastoris and its application to reduce Aeromonas hydrophila mortality in aquaculture. Microb. Cell Fact. 9, 39. doi: 10.1186/1475-2859-9-39

Chmielewski, R. A. N., and Frank, J. F. (2003). Biofilm formation and control in food processing facilities. Compr. Rev. Food Sci. Food Saf. 2, 22-32. doi: 10.1111/j.1541-4337.2003.tb00012.x

Christiaen, S. E., Brackman, G., Nelis, H. J., and Coenye, T. (2011). Isolation and identification of quorum quenching bacteria from environmental samples. J. Microbiol. Methods 87, 213-219. doi: 10.1016/j.mimet.2011. 08.002
Claessen, D., Rozen, D. E., Kuipers, O. P., Sogaard-Andersen, L., and van Wezel, G. P. (2014). Bacterial solutions to multicellularity: a tale of biofilms, filaments and fruiting bodies. Nat. Rev. Microbiol. 12, 115-124. doi: 10.1038/nrmicro3178

Cloete, T. E., and Jacobs, L. (2001). Surfactants and the attachment of Pseudomonas aeruginosa to 3CR12 stainless steel and glass. Water SA 27, 21-26.

Cookson, A. L., Cooley, W. A., and Woodward, M. J. (2002). The role of type 1 and curli fimbriae of Shiga toxin-producing Escherichia coli in adherence to abiotic surfaces. Int. J. Med. Microbiol. 292, 195-205. doi: 10.1078/1438-422100203

Costerton, J. W., Irvin, R. T., and Cheng, K. J. (1981). The bacterial glycocalyx in nature and disease. Annu. Rev. Microbiol. 35, 299-324. doi: 10.1146/annurev.mi.35.100181.001503

Coton, M., Delbés-Paus, C., Irlinger, F., Desmasures, N., Le Fleche, A., Stahl, V., et al. (2012). Diversity and assessment of potential risk factors of Gramnegative isolates associated with French cheeses. Food Microbiol. 29, 88-98. doi: 10.1016/j.fm.2011.08.020

Cotter, P. D., Hill, C., and Ross, R. P. (2005). Bacteriocins: developing innate immunity for food. Nat. Rev. Microbiol. 3, 777-788. doi: 10.1038/nrmicro1273

Coughlan, L. M., Cotter, P. D., Hill, C., and Alvarez-Ordóñez, A. (2015). Biotechnological applications of functional metagenomics in the food and pharmaceutical industries. Front. Microbiol. 6:672. doi: 10.3389/fmicb.2015.00672

Craigen, B., Dashiff, A., and Kadouri, D. E. (2011). The use of commercially available alpha-amylase compounds to inhibit and remove Staphylococcus aureus biofilms. Open Microbiol. J. 5, 21-31. doi: 10.2174/1874285801105010021

Croxatto, A., Chalker, V. J., Lauritz, J., Jass, J., Hardman, A., Williams, P., et al. (2002). VanT, a homologue of Vibrio harveyi LuxR, regulates serine, metalloprotease, pigment, and biofilm production in Vibrio anguillarum. J. Bacteriol. 184, 1617-1629. doi: 10.1128/JB.184.6.1617-1629.2002

Crump, J. A., and Mintz, E. D. (2010). Global trends in typhoid and paratyphoid fever. Clin. Infect. Dis. 50, 241-246. doi: 10.1086/649541

da Silva, E., and De Martinis, E. (2013). Current knowledge and perspectives on biofilm formation: the case of Listeria monocytogenes. Appl. Microbiol. Biotechnol. 97, 957-968. doi: 10.1007/s00253-012-4611-1

Dewanti, R., and Wong, A. C. L. (1995). Influence of culture conditions on biofilm formation by Escherichia coli O157:H7. Int. J. Food Microbiol. 26, 147-164. doi: 10.1016/0168-1605(94)00103-D

Di Bonaventura, G., Piccolomini, R., Paludi, D., D’Orio, V., Vergara, A., Conter, M., et al. (2008). Influence of temperature on biofilm formation by Listeria monocytogenes on various food-contact surfaces: relationship with motility and cell surface hydrophobicity. J. Appl. Microbiol. 104, 1552-1561. doi: 10.1111/j.1365-2672.2007.03688.x

Dong, Y.-H., Wang, L.-H., Xu, J.-L., Zhang, H.-B., Zhang, X.-F., and Zhang, L.-H. (2001). Quenching quorum-sensing-dependent bacterial infection by an N-acyl homoserine lactonase. Nature 411, 813-817. doi: 10.1038/35081101

Dong, Y.-H., Xu, J.-L., Li, X.-Z., and Zhang, L.-H. (2000). AiiA, an enzyme that inactivates the acylhomoserine lactone quorum-sensing signal and attenuates the virulence of Erwinia carotovora. Proc. Natl. Acad. Sci. U.S.A. 97, 3526-3531. doi: 10.1073/pnas.97.7.3526

Donlan, R. M. (2009). Preventing biofilms of clinically relevant organisms using bacteriophage. Trends Microbiol. 17, 66-72. doi: 10.1016/j.tim.2008.11.002

Duanis-Assaf, D., Steinberg, D., Chai, Y., and Shemesh, M. (2015). The LuxS based quorum sensing governs lactose induced biofilm formation by Bacillus subtilis. Front. Microbiol. 6:1517. doi: 10.3389/fmicb.2015.01517

Dykes, G. A., and Moorhead, S. M. (2000). Survival of osmotic and acid stress by Listeria monocytogenes strains of clinical or meat origin. Int. J. Food Microbiol. 56, 161-166. doi: 10.1016/S0168-1605(99)00205-6

Dzieciol, M., Schornsteiner, E., Muhterem-Uyar, M., Stessl, B., Wagner, M., and Schmitz-Esser, S. (2016). Bacterial diversity of floor drain biofilms and drain waters in a Listeria monocytogenes contaminated food processing environment. Int. J. Food Microbiol. 223, 33-40. doi: 10.1016/j.ijfoodmicro.2016.02.004

EFSA (2009). The community summary report on trends and sources of zoonoses and zoonotic agents in the European Union in 2007. EFSA J. 2009:223. doi: 10.2903/j.efsa.2009.223r

Endersen, L., O’Mahony, J., Hill, C., Ross, R. P., McAuliffe, O., and Coffey, A. (2014). Phage therapy in the food industry. Annu. Rev. Food Sci. Technol. 5, 327-349. doi: 10.1146/annurev-food-030713-092415 
Ercolini, D., Russo, F., Ferrocino, I., and Villani, F. (2009). Molecular identification of mesophilic and psychrotrophic bacteria from raw cow's milk. Food Microbiol. 26, 228-231. doi: 10.1016/j.fm.2008.09.005

Faille, C., and Carpentier, B. (2009). "11 - Food contact surfaces, surface soiling and biofilm formation," in Biofilms in the Food and Beverage Industries, eds P. M. Fratamico, B. A. Annous and N. W. Gunther. (Oxford: Woodhead Publishing), 303-330.

Favre-Bonte, S., Kohler, T., and Van Delden, C. (2003). Biofilm formation by Pseudomonas aeruginosa: role of the C4-HSL cell-to-cell signal and inhibition by azithromycin. J. Antimicrob Chemother. 52, 598-604. doi: $10.1093 / \mathrm{jac} / \mathrm{dkg} 397$

Fenton, M., Keary, R., McAuliffe, O., Ross, R. P., O’Mahony, J., and Coffey, A. (2013). Bacteriophage-derived peptidase eliminates and prevents Staphylococcal biofilms. Int. J. Microbiol. 2013:625341. doi: 10.1155/2013/ 625341

Field, D., Gaudin, N., Lyons, F., O'Connor, P. M., Cotter, P. D., Hill, C., et al. (2015). A Bioengineered nisin derivative to control biofilms of Staphylococcus pseudintermedius. PLoS ONE 10: e0119684. doi: 10.1371/journal.pone.0119684

Flemming, H.-C., and Wingender, J. (2010). The biofilm matrix. Nat. Rev. Microbiol. 8, 623-633.

Freitag, N. E., Port, G. C., and Miner, M. D. (2009). Listeria monocytogenes [mdash] from saprophyte to intracellular pathogen. Nat. Rev. Microbiol. 7, 623-628. doi: $10.1038 /$ nrmicro2171

Fuqua, W. C., Winans, S. C., and Greenberg, E. P. (1994). Quorum sensing in bacteria: the LuxR-LuxI family of cell density-responsive transcriptional regulators. J. Bacteriol. 176, 269-275.

Gahan, C. G. M., and Hill, C. (2014). Listeria monocytogenes: survival and adaptation in the gastrointestinal tract. Front. Cell. Infect. Microbiol. 4: 9. doi: 10.3389/fcimb.2014.00009

García-Almendárez, B.E., Cann, I.K.O., Martin, S.E., Guerrero-Legarreta, I., and Regalado, C. (2008). Effect of Lactococcus lactis UQ2 and its bacteriocin on Listeria monocytogenes biofilms. Food Control 19, 670-680. doi: 10.1016/j.foodcont.2007.07.015

Gilbert, P., Allison, D. G., and McBain, A. J. (2002). Biofilms in vitro and in vivo: do singular mechanisms imply cross-resistance? J. Appl. Microbiol. 92, 98S-110S. doi: 10.1046/j.1365-2672.92.5s1.5.x

Girennavar, B., Cepeda, M. L., Soni, K. A., Vikram, A., Jesudhasan, P., Jayaprakasha, G. K., et al. (2008). Grapefruit juice and its furocoumarins inhibits autoinducer signaling and biofilm formation in bacteria. Int. J. Food Microbiol. 125, 204-208. doi: 10.1016/j.ijfoodmicro.2008.03.028

Gopal, N., Hill, C., Ross, P. R., Beresford, T. P., Fenelon, M. A., and Cotter, P. D. (2015). The Prevalence and control of Bacillus and related sporeforming bacteria in the dairy industry. Front. Microbiol. 6: 1418. doi: 10.3389/fmicb. 2015.01418

Gu, H., Lee, S. W., Buffington, S. L., Henderson, J. H., and Ren, D. (2016). Ondemand removal of bacterial biofilms via shape memory activation. ACS Appl. Mater. Interfaces 8, 21140-21144. doi: 10.1021/acsami.6b06900

Guenther, S., Huwyler, D., Richard, S., and Loessner, M. J. (2009). Virulent bacteriophage for efficient biocontrol of Listeria monocytogenes in ready-to-eat foods. Appl. Environ. Microbiol. 75, 93-100. doi: 10.1128/AEM.01711-08

Hall-Stoodley, L., Costerton, J. W., and Stoodley, P. (2004). Bacterial biofilms: from the natural environment to infectious diseases. Nat. Rev. Microbiol. 2, 95-108. doi: $10.1038 /$ nrmicro821

Hamon, M., Bierne, H., and Cossart, P. (2006). Listeria monocytogenes: a multifaceted model. Nat. Rev. Microbiol. 4, 423-434. doi: 10.1038/nrmicro1413

Harmsen, M., Lappann, M., Knøchel, S., and Molin, S. (2010). Role of extracellular DNA during biofilm formation by Listeria monocytogenes. Appl. Environ. Microbiol. 76, 2271-2279. doi: 10.1128/AEM.02361-09

Hoffmann, S., Maculloch, B., and Batz, M. (2015). Economic Burden of Major Foodborne Illnesses Acquired in the United States, EIB-140. Washington, DC: United States Department of Agriculture. Available at: http://www.ers.usda.gov /media/1837791/eib140.pdf

Huang, J. J., Han, J. I., Zhang, L. H., and Leadbetter, J. R. (2003). Utilization of acyl-homoserine lactone quorum signals for growth by a soil pseudomonad and Pseudomonas aeruginosa PAO1. Appl. Environ. Microbiol. 69, 5941-5949. doi: 10.1128/AEM.69.10.5941-5949.2003

Jackson, B. R., Griffin, P. M. G., Cole, D., Walsh, K. A., and Chai, S. J. (2013). Outbreak-associated Salmonella enterica serotypes and food commodities, United States, 1998-2008. Emerg. Infect. Dis. 19, 1239-1244. doi: 10.3201/eid1908.121511

Jahid, I., and Ha, S.-D. (2012). A review of microbial biofilms of produce: future challenge to food safety. Food Sci. Biotechnol. 21, 299-316. doi: 10.1007/s10068012-0041-1

Kalai Chelvam, K., Chai, L. C., and Thong, K. L. (2014). Variations in motility and biofilm formation of Salmonella enterica serovar Typhi. Gut Pathog. 6, 1-10. doi: 10.1186/1757-4749-6-2

Kaplan, J. B. (2010). Biofilm dispersal: mechanisms, clinical implications, and potential therapeutic uses. J. Dent. Res. 89, 205-218. doi: $10.1177 / 0022034509359403$

Karatan, E., and Watnick, P. (2009). Signals, regulatory networks, and materials that build and break bacterial biofilms. Microbiol. Mol. Biol. Rev. 73, 310-347. doi: 10.1128/MMBR.00041-08

Kelly, D., McAuliffe, O., Ross, R. P., and Coffey, A. (2012). Prevention of Staphylococcus aureus biofilm formation and reduction in established biofilm density using a combination of phage $\mathrm{K}$ and modified derivatives. Lett. Appl. Microbiol. 54, 286-291. doi: 10.1111/j.1472-765X.2012.03205.x

Kim, S.-H., Park, C., Lee, E.-J., Bang, W.-S., Kim, Y.-J., and Kim, J.-S. (2017). Biofilm formation of Campylobacter strains isolated from raw chickens and its reduction with DNase I treatment. Food Control 71, 94-100. doi: 10.1016/j.foodcont.2016.06.038

Koh, C.-L., Sam, C.-K., Yin, W.-F., Tan, L. Y., Krishnan, T., Chong, Y. M., et al. (2013). Plant-derived natural products as sources of anti-quorum sensing compounds. Sensors 13, 6217-6228. doi: 10.3390/s130506217

Krysciak, D., Schmeisser, C., Preuß, S., Riethausen, J., Quitschau, M., Grond, S., et al. (2011). Involvement of multiple loci in quorum quenching of autoinducer I molecules in the nitrogen-fixing symbiont Rhizobium (Sinorhizobium) sp. Strain NGR234. Appl. Environ. Microbiol. 77, 5089-5099. doi: 10.1128/AEM.00112-11

Kusari, P., Kusari, S., Lamshöft, M., Sezgin, S., Spiteller, M., and Kayser, O. (2014). Quorum quenching is an antivirulence strategy employed by endophytic bacteria. Appl. Microbiol. Biotechnol. 98, 7173-7183. doi: 10.1007/s00253-0145807-3

Laroussi, M. (1996). Sterilization of contaminated matter with an atmospheric pressure plasma. IEEE Trans. Plasma Sci. 24, 1188-1191. doi: 10.1109/27.533129

Le Thi, T.-T., Prigent-Combaret, C., Dorel, C., and Lejeune, P. (2001). “[15] First stages of biofilm formation: Characterization and quantification of bacterial functions involved in colonization process," in Methods in Enzymology, ed. J. D. Ron (Cambridge, MA: Academic Press), 152-159.

Leong, D., Alvarez-Ordonez, A., and Jordan, K. (2014). Monitoring occurrence and persistence of Listeria monocytogenes in foods and food processing environments in the republic of Ireland. Front. Microbiol. 5:436. doi: $10.3389 /$ fmicb. 2014.00436

Lequette, Y., Boels, G., Clarisse, M., and Faille, C. (2010). Using enzymes to remove biofilms of bacterial isolates sampled in the food-industry. Biofouling 26, 421-431. doi: 10.1080/08927011003699535

Leroy, F., and De Vuyst, L. (2004). Lactic acid bacteria as functional starter cultures for the food fermentation industry. Trends Food Sci. Technol. 15, 67-78. doi: 10.1016/j.tifs.2003.09.004

Lin, Y. H., Xu, J. L., Hu, J., Wang, L. H., Ong, S. L., Leadbetter, J. R., et al. (2003). Acyl-homoserine lactone acylase from Ralstonia strain XJ12B represents a novel and potent class of quorum-quenching enzymes. Mol. Microbiol. 47, 849-860. doi: 10.1046/j.1365-2958.2003.03351.x

Listex (2006). LISTEX Against Listeria: 100\% Natural and Organic [Online]. Available at: http://www.listex.eu/

Liu, M., Wang, H., and Griffiths, M. W. (2007). Regulation of alkaline metalloprotease promoter by $\mathrm{N}$-acyl homoserine lactone quorum sensing in Pseudomonas fluorescens. J. Appl. Microbiol. 103, 2174-2184. doi: 10.1111/j.1365-2672.2007.03488.x

Lu, T. K., and Collins, J. J. (2007). Dispersing biofilms with engineered enzymatic bacteriophage. Proc. Natl. Acad. Sci. U.S.A. 104, 11197-11202. doi: 10.1073/pnas.0704624104

Luppens, S. B. I., Reij, M. W., van der Heijden, R. W. L., Rombouts, F. M., and Abee, T. (2002). Development of a standard test to assess the resistance of Staphylococcus aureus biofilm cells to disinfectants. Appl. Environ. Microbiol. 68, 4194-4200. doi: 10.1128/AEM.68.9.4194-4200.2002 
Ma, M., Li, J., and McClane, B. A. (2015). Structure-function analysis of peptide signaling in the Clostridium perfringens Agr-like quorum sensing system. J. Bacteriol. 197, 1807-1818. doi: 10.1128/JB.02614-14

Maderova, Z., Horska, K., Kim, S.-R., Lee, C.-H., Pospiskova, K., Safarikova, M., et al. (2016). Decrease of Pseudomonas aeruginosa biofilm formation by food waste materials. Water Sci. Technol. 73, 2143-2149. doi: 10.2166/wst. 2016.058

Mandlik, A., Swierczynski, A., Das, A., and Ton-That, H. (2008). Pili in Gram-positive bacteria: assembly, involvement in colonization and biofilm development. Trends Microbiol. 16, 33-40. doi: 10.1016/j.tim.2007.10.010

Manefield, M., Rasmussen, T. B., Henzter, M., Andersen, J. B., Steinberg, P., Kjelleberg, S., et al. (2002). Halogenated furanones inhibit quorum sensing through accelerated LuxR turnover. Microbiology 148, 1119-1127. doi: 10.1099/00221287-148-4-1119

Marchand, S., De Block, J., De Jonghe, V., Coorevits, A., Heyndrickx, M., and Herman, L. (2012). Biofilm formation in milk production and processing environments; influence on milk quality and safety. Compr. Rev. Food Sci. Food Saf. 11, 133-147. doi: 10.1111/j.1541-4337.2011.00183.x

Marchand, S., Vandriesche, G., Coorevits, A., Coudijzer, K., De Jonghe, V., Dewettinck, K., et al. (2009). Heterogeneity of heat-resistant proteases from milk Pseudomonas species. Int. J. Food Microbiol. 133, 68-77. doi: 10.1016/j.ijfoodmicro.2009.04.027

McDougald, D., Rice, S. A., Barraud, N., Steinberg, P. D., and Kjelleberg, S. (2012). Should we stay or should we go: mechanisms and ecological consequences for biofilm dispersal. Nat. Rev. Microbiol. 10, 39-50. doi: 10.1038/nrmicro2695

Mei, G.-Y., Yan, X.-X., Turak, A., Luo, Z.-Q., and Zhang, L.-Q. (2010). AidH, an Alpha/Beta-hydrolase fold family member from an Ochrobactrum sp. strain, is a novel N-acylhomoserine lactonase. Appl. Environ. Microbiol. 76, 4933-4942. doi: 10.1128/AEM.00477-10

Melaugh, G., Hutchison, J., Kragh, K. N., Irie, Y., Roberts, A., Bjarnsholt, T., et al. (2016). Shaping the growth behaviour of biofilms initiated from bacterial aggregates. PLoS ONE 11: e0149683. doi: 10.1371/journal.pone.0149683

Molobela, I. P., Cloete, T. E., and Beukes, M. (2010). Protease and amylase enzymes for biofilm removal and degradation of extracellular polymeric substances (EPS) produced by Pseudomonas fluorescens bacteria. Afr. J. Microbiol. Res. 4, 1515-1524.

Morohoshi, T., Nakazawa, S., Ebata, A., Kato, N., and Ikeda, T. (2008). Identification and characterization of $\mathrm{N}$-acylhomoserine lactone-acylase from the fish intestinal Shewanella sp. Strain MIB015. Biosci. Biotechnol. Biochem. 72, 1887-1893. doi: 10.1271/bbb.80139

Morohoshi, T., Tominaga, Y., Someya, N., and Ikeda, T. (2012). Complete genome sequence and characterization of the $\mathrm{N}$-acylhomoserine lactone-degrading gene of the potato leaf-associated Solibacillus silvestris. J. Biosci. Bioeng. 113, 20-25. doi: 10.1016/j.jbiosc.2011.09.006

Morohoshi, T., Wang, W.-Z., Someya, N., and Ikeda, T. (2011). Genome sequence of Microbacterium testaceum StLB037, an N-acylhomoserine lactone-degrading bacterium isolated from potato leaves. J. Bacteriol. 193, 2072-2073. doi: 10.1128/JB.00180-11

Myszka, K., Schmidt, M. T., Majcher, M., Juzwa, W., Olkowicz, M., and Czaczyk, K. (2016). Inhibition of quorum sensing-related biofilm of Pseudomonas fluorescens KM121 by Thymus vulgare essential oil and its major bioactive compounds. Int. Biodeterior. Biodegradation 114, 252-259. doi: 10.1016/j.ibiod.2016.07.006

Nachamkin, I., Allos, B. M., and Ho, T. (1998). Campylobacter species and guillain-barré syndrome. Clin. Microbiol. Rev. 11, 555-567.

National Institutes of Health (2002). Research on Microbial Biofilms (PA-03047). Available at: http://grants.nih.gov/grants/guide/pa-files/PA-03-047.html (accessed January 10, 2015).

Neyret, C., Herry, J. -M., Meylheuc, T., and Dubois-Brissonnet, F. (2014). Plant-derived compounds as natural antimicrobials to control paper mill biofilms. J. Ind. Microbiol. Biotechnol. 41, 87-96. doi: 10.1007/s10295-0131365-4

Nickel, J. C., Ruseska, I., Wright, J. B., and Costerton, J. W. (1985). Tobramycin resistance of Pseudomonas aeruginosa cells growing as a biofilm on urinary catheter material. Antimicrob. Agents Chemother. 27, 619-624. doi: 10.1128/AAC.27.4.619

Niu, C., Robbins, C. M., Pittman, K. J., Osborn, J. L., Stubblefield, B. A., Simmons, R. B., et al. (2013). LuxS influences Escherichia coli biofilm formation through autoinducer-2-dependent and autoinducer-2-independent modalities. FEMS Microbiol. Ecol. 83, 778-791. doi: 10.1111/1574-6941.12034

Nostro, A., Roccaro, A. S., Bisignano, G., Marino, A., Cannatelli, M. A., Pizzimenti, F. C., et al. (2007). Effects of oregano, carvacrol and thymol on Staphylococcus aureus and Staphylococcus epidermidis biofilms. J. Med. Microbiol. 56, 519-523. doi: 10.1099/jmm.0.46804-0

O'Leary, D., McCabe, E. M., McCusker, M. P., Martins, M., Fanning, S., and Duffy, G. (2015). Acid environments affect biofilm formation and gene expression in isolates of Salmonella enterica Typhimurium DT104. Int. J. Food Microbiol. 206, 7-16. doi: 10.1016/j.ijfoodmicro.2015. 03.030

Orgaz, B., Kives, J., Pedregosa, A. M., Monistrol, I. F., Laborda, F., and SanJosé, C. (2006). Bacterial biofilm removal using fungal enzymes. Enzyme Microb. Technol. 40, 51-56. doi: 10.1016/j.enzmictec.2005.10.037

Oulahal, N., Martial-Gros, A., Bonneau, M., and Blum, L. J. (2007). Removal of meat biofilms from surfaces by ultrasounds combined with enzymes and/or a chelating agent. Innov. Food Sci. Emerg. Technol. 8, 192-196. doi: 10.1016/j.ifset.2006.10.001

Oulahal-Lagsir, N., Martial-Gros, A., Bonneau, M., and Blum, L. J. (2003). "Escherichia coli-milk" biofilm removal from stainless steel surfaces: synergism between ultrasonic waves and enzymes. Biofouling 19, 159-168. doi: 10.1080/08927014.2003.10382978

Palmer, J. S., Flint, S. H., Schmid, J., and Brooks, J. D. (2010). The role of surface charge and hydrophobicity in the attachment of Anoxybacillus flavithermus isolated from milk powder. J. Ind. Microbiol. Biotechnol. 37, 1111-1119. doi: 10.1007/s10295-010-0758-x

Peng, J.-S., Tsai, W.-C., and Chou, C.-C. (2002). Inactivation and removal of Bacillus cereus by sanitizer and detergent. Int. J. Food Microbiol. 77, 11-18. doi: 10.1016/S0168-1605(02)00060-0

Pereira, A., Mendes, J., and Melo, L. F. (2008). Using nanovibrations to monitor biofouling. Biotechnol. Bioeng. 99, 1407-1415. doi: 10.1002/bit. 21696

Pereira, A., Mendes, J., and Melo, L. F. (2009). Monitoring cleaning-in-place of shampoo films using nanovibration technology. Sens. Actuators B Chem. 136, 376-382. doi: 10.1016/j.snb.2008.11.043

Pérez-Ibarreche, M., Castellano, P., Leclercq, A., and Vignolo, G. (2016). Control of Listeria monocytogenes biofilms on industrial surfaces by the bacteriocinproducing Lactobacillus sakei CRL1862. FEMS Microbiol. Lett. 363:fnw118. doi: 10.1093/femsle/fnw118

Persat, A., Nadell, C. D., Kim, M. K., Ingremeau, F., Siryaporn, A., Drescher, K., et al. (2015). The mechanical world of bacteria. Cell 161, 988-997. doi: 10.1016/j.cell.2015.05.005

Peterson, R. V., and Pitt, W. G. (2000). The effect of frequency and power density on the ultrasonically-enhanced killing of biofilm-sequestered Escherichia coli. Colloids Surf. B Biointerfaces 17, 219-227. doi: 10.1016/S0927-7765(99) 00117-4

Petrova, M. I., Imholz, N. C. E., Verhoeven, T. L. A., Balzarini, J., Van Damme, E. J. M., Schols, D., et al. (2016). Lectin-like molecules of Lactobacillus rhamnosus GG inhibit pathogenic Escherichia coli and Salmonella biofilm formation. PLoS ONE 11: e0161337. doi: 10.1371/journal.pone.0161337

Petrova, O. E., and Sauer, K. (2012). Sticky situations: key components that control bacterial surface attachment. J. Bacteriol. 194, 2413-2425. doi: 10.1128/JB.00003-12

Pilchová, T., Hernould, M., Prévost, H., Demnerová, K., Pazlarová, J., and Tresse, O. (2014). Influence of food processing environments on structure initiation of static biofilm of Listeria monocytogenes. Food Control 35, 366-372. doi: 10.1016/j.foodcont.2013.07.021

Pinto, U. M., de Souza Viana, E., Martins, M. L., and Vanetti, M. C. D. (2007). Detection of acylated homoserine lactones in gram-negative proteolytic psychrotrophic bacteria isolated from cooled raw milk. Food Control 18, 13221327. doi: 10.1016/j.foodcont.2006.09.005

Pope, J. E., Krizova, A., Garg, A. X., Thiessen-Philbrook, H., and Ouimet, J. M. (2007). Campylobacter reactive Arthritis: a systematic review. Semin. Arthritis Rheum. 37, 48-55. doi: 10.1016/j.semarthrit.2006.12.006

Rasmussen, T. B., Bjarnsholt, T., Skindersoe, M. E., Hentzer, M., Kristoffersen, P., Köte, M., et al. (2005). Screening for Quorum-Sensing Inhibitors (QSI) by use of a novel genetic system, the QSI selector. J. Bacteriol. 187, 1799-1814. doi: 10.1128/JB.187.5.1799-1814.2005 
Reeser, R. J., Medler, R. T., Billington, S. J., Jost, B. H., and Joens, L. A. (2007). Characterization of Campylobacter jejuni biofilms under defined growth conditions. Appl. Environ. Microbiol. 73, 1908-1913. doi: 10.1128/AEM. 00740-06

Riedel, C. U., Monk, I. R., Casey, P. G., Waidmann, M. S., Gahan, C. G., and Hill, C. (2009). AgrD-dependent quorum sensing affects biofilm formation, invasion, virulence and global gene expression profiles in Listeria monocytogenes. Mol. Microbiol. 71, 1177-1189. doi: 10.1111/j.1365-2958.2008. 06589.x

Rodríguez-Guardado, A., Boga, J. A., Diego, I. D., Ordás, J., Álvarez, M. E., and Pérez, F. (2005). Clinical characteristics of nosocomial and communityacquired extraintestinal infections caused by Hafnia alvei. Scand. J. Infect. Dis. 37, 870-872. doi: 10.1080/00365540500333699

Safefood (2012). Whitepaper. Cleaning and Disinfection in Food Processing Operations. New York: Safefood 360, Inc. Available at: http://safefood360.com/ resources/Cleaning.pdf

Scallan, E., Hoekstra, R. M., Angulo, F. J., Tauxe, R. V., Widdowson, M. A., Roy, S. L., et al. (2011). Foodborne illness acquired in the United States-major pathogens. Emerg. Infect. Dis. 17, 7-15. doi: 10.3201/eid1701.091101p1

Schipper, C., Hornung, C., Bijtenhoorn, P., Quitschau, M., Grond, S., and Streit, W. R. (2009). Metagenome-derived clones encoding two novel lactonase family proteins involved in biofilm inhibition in Pseudomonas aeruginosa. Appl. Environ. Microbiol. 75, 224-233. doi: 10.1128/AEM.01389-08

Schwille-Kiuntke, J., Enck, P., Zendler, C., Krieg, M., Polster, A. V., Klosterhalfen, S., et al. (2011). Postinfectious irritable bowel syndrome: follow-up of a patient cohort of confirmed cases of bacterial infection with Salmonella or Campylobacter. Neurogastroenterol. Motility 23, e479-e488. doi: 10.1111/j.1365-2982.2011.01779.x

Sela, S., Frank, S., Belausov, E., and Pinto, R. (2006). A mutation in the luxS gene influences Listeria monocytogenes biofilm formation. Appl. Environ. Microbiol. 72, 5653-5658. doi: 10.1128/AEM.00048-06

Sharma, M., and Anand, S. K. (2002). Biofilms evaluation as an essential component of HACCP for food/dairy processing industry - a case. Food Control 13, 469-477. doi: 10.1016/S0956-7135(01)00068-8

Shen, G., Rajan, R., Zhu, J., Bell, C. E., and Pei, D. (2006). Design and synthesis of substrate and intermediate analogue inhibitors of S-ribosylhomocysteinase. J. Med. Chem. 49, 3003-3011. doi: 10.1021/jm060047g

Shikongo-Nambabi, M. N., Kachigunda, B., and Venter, S. N. (2010). Evaluation of oxidising disinfectants to control Vibrio biofilms in treated seawater used for fish processing. Water Sa 36, 215-220.

Sillankorva, S., Oliveira, R., Vieira, M. J., Sutherland, I., and Azeredo, J. (2004). Bacteriophage $\Phi$ S1 infection of Pseudomonas fluorescens planktonic cells versus biofilms. Biofouling 20, 133-138. doi: 10.1080/08927010410001723834

Simões, M., Simões, L. C., and Vieira, M. J. (2010). A review of current and emergent biofilm control strategies. LWT Food Sci. Technol. 43, 573-583. doi: 10.1016/j.lwt.2009.12.008

Sio, C. F., Otten, L. G., Cool, R. H., Diggle, S. P., Braun, P. G., Bos, R., et al. (2006). Quorum quenching by an N-acyl-homoserine lactone acylase from Pseudomonas aeruginosa PAO1. Infect. Immun. 74, 1673-1682. doi: 10.1128/IAI.74.3.1673-1682.2006

Skandamis, P. N., and Nychas, G. J. (2012). Quorum sensing in the context of food microbiology. Appl. Environ. Microbiol. 78, 5473-5482. doi: 10.1128/AEM.00468-12

Soni, K. A., and Nannapaneni, R. (2010). Removal of Listeria monocytogenes biofilms with bacteriophage P100. J. Food Prot. 73, 1519-1524.

Sperandio, V., Torres, A. G., Jarvis, B., Nataro, J. P., and Kaper, J. B. (2003). Bacteria-host communication: the language of hormones. Proc. Natl. Acad. Sci. U.S.A. 100, 8951-8956. doi: 10.1073/pnas.1537100100

Srey, S., Jahid, I. K., and Ha, S.-D. (2013). Biofilm formation in food industries: a food safety concern. Food Control 31, 572-585. doi: 10.1016/j.foodcont.2012.12.001

Steenackers, H., Hermans, K., Vanderleyden, J., and De Keersmaecker, S. C. J. (2012). Salmonella biofilms: an overview on occurrence, structure, regulation and eradication. Food Res. Int. 45, 502-531. doi: 10.1016/j.foodres.2011.01.038

Stewart, P. S., and William Costerton, J. (2001). Antibiotic resistance of bacteria in biofilms. Lancet 358, 135-138. doi: 10.1016/S0140-6736(01)05321-1

Stiefel, P., Rosenberg, U., Schneider, J., Mauerhofer, S., Maniura-Weber, K., and Ren, Q. (2016). Is biofilm removal properly assessed? Comparison of different quantification methods in a 96-well plate system. Appl. Microbiol. Biotechnol. 100, 4135-4145. doi: 10.1007/s00253-016-7396-9

Sutherland, I. W. (1983). Microbial exopolysaccharides - their role in microbial adhesion in aqueous systems. Crit. Rev. Microbiol. 10, 173-201. doi: $10.3109 / 10408418209113562$

Tan, C. H., Koh, K. S., Xie, C., Tay, M., Zhou, Y., Williams, R., et al. (2014). The role of quorum sensing signalling in EPS production and the assembly of a sludge community into aerobic granules. ISME J. 8, 1186-1197. doi: 10.1038/ismej.2013.240

Tan, C. H., Koh, K. S., Xie, C., Zhang, J., Tan, X. H., Lee, G. P., et al. (2015). Community quorum sensing signalling and quenching: microbial granular biofilm assembly. Npj Biofilms Microbiomes 1:15006. doi: 10.1038/npjbiofilms.2015.6

Teh, A. H. T., Lee, S. M., and Dykes, G. A. (2014). Does Campylobacter jejuni form biofilms in food-related environments? Appl. Environ. Microbiol. 80, 5154-5160. doi: 10.1128/AEM.01493-14

Toté, K., Horemans, T., Berghe, D. V., Maes, L., and Cos, P. (2010). Inhibitory effect of biocides on the viable masses and matrices of Staphylococcus aureus and Pseudomonas aeruginosa biofilms. Appl. Environ. Microbiol. 76, 3135-3142. doi: 10.1128/AEM.02095-09

Tresse, O., Lebret, V., Benezech, T., and Faille, C. (2006). Comparative evaluation of adhesion, surface properties, and surface protein composition of Listeria monocytogenes strains after cultivation at constant $\mathrm{pH}$ of 5 and 7. J. Appl. Microbiol. 101, 53-62. doi: 10.1111/j.1365-2672.2006.02968.x

Tresse, O., Lebret, V., Garmyn, D., and Dussurget, O. (2009). The impact of growth history and flagellation on the adhesion of various Listeria monocytogenes strains to polystyrene. Can. J. Microbiol. 55, 189-196. doi: 10.1139/ W08-114

Uroz, S., and Heinonsalo, J. (2008). Degradation of N-acyl homoserine lactone quorum sensing signal molecules by forest root-associated fungi. FEMS Microbiol. Ecol. 65, 271-278. doi: 10.1111/j.1574-6941.2008. 00477.x

Uroz, S., Oger, P., Chhabra, S., Cámara, M., Williams, P., and Dessaux, Y. (2007). N-acyl homoserine lactones are degraded via an amidolytic activity in Comamonas sp. strain D1. Arch. Microbiol. 187, 249-256. doi: 10.1007/s00203006-0186-5

Uroz, S., Oger, P. M., Chapelle, E., Adeline, M.-T., Faure, D., and Dessaux, Y. (2008). A Rhodococcus qsdA-encoded enzyme defines a novel class of largespectrum quorum-quenching lactonases. Appl. Environ. Microbiol. 74, 13571366. doi: 10.1128/AEM.02014-07

van der Veen, S., and Abee, T. (2011). Mixed species biofilms of Listeria monocytogenes and Lactobacillus plantarum show enhanced resistance to benzalkonium chloride and peracetic acid. Int. J. Food Microbiol. 144, 421-431. doi: 10.1016/j.ijfoodmicro.2010.10.029

Van Houdt, R., Aertsen, A., Jansen, A., Quintana, A. L., and Michiels, C. W. (2004). Biofilm formation and cell-to-cell signalling in Gram-negative bacteria isolated from a food processing environment. J. Appl. Microbiol. 96, 177-184. doi: 10.1046/j.1365-2672.2003.02131.x

Van Houdt, R., and Michiels, C. W. (2010). Biofilm formation and the food industry, a focus on the bacterial outer surface. J. Appl. Microbiol. 109, $1117-$ 1131. doi: 10.1111/j.1365-2672.2010.04756.x

Vandervoort, K. G., and Brelles-Mariño, G. (2014). Plasma-mediated inactivation of Pseudomonas aeruginosa biofilms grown on borosilicate surfaces under continuous culture system. PLoS ONE 9:e108512. doi: 10.1371/journal.pone.0108512

Viana, E. S., Campos, M. E., Ponce, A. R., Mantovani, H. C., and Vanetti, M. C. (2009). Biofilm formation and acyl homoserine lactone production in Hafnia alvei isolated from raw milk. Biol. Res. 42, 427-436. doi: 10.4067/S071697602009000400004

Vidal, J. E., Shak, J. R., and Canizalez-Roman, A. (2015). The CpAL quorum sensing system regulates production of hemolysins CPA and PFO To Build Clostridium perfringens Biofilms. Infect. Immun. 83, 2430-2442. doi: 10.1128/IAI. 00240-15

Wahjudi, M., Papaioannou, E., Hendrawati, O., van Assen, A. H. G., van Merkerk, R., Cool, R. H., et al. (2011). PA0305 of Pseudomonas aeruginosa is a quorum quenching acylhomoserine lactone acylase belonging to the Ntn hydrolase superfamily. Microbiology 157, 2042-2055. doi: $10.1099 / \mathrm{mic} .0 .043935-0$ 
Walker, S. J., Archer, P., and Banks, J. G. (1990). Growth of Listeria monocytogenes at refrigeration temperatures. J. Appl. Bacteriol. 68, 157-162. doi: 10.1111/j.1365-2672.1990.tb02561.x

Walker, S. L., Fourgialakis, M., Cerezo, B., and Livens, S. (2007). Removal of microbial biofilms from dispense equipment: the effect of enzymatic predigestion and detergent treatment. J. Inst. Brew. 113, 61-66. doi: 10.1002/j.20500416.2007.tb00257.x

Walters, M., Sircili, M. P., and Sperandio, V. (2006). AI-3 synthesis is not dependent on luxS in Escherichia coli. J. Bacteriol. 188, 5668-5681. doi: 10.1128/JB.00648-06

Wang, H., Wang, H., Xing, T., Wu, N., Xu, X., and Zhou, G. (2016). Removal of Salmonella biofilm formed under meat processing environment by surfactant in combination with bio-enzyme. LWT Food Sci. Technol. 66, 298-304. doi: 10.1016/j.lwt.2015.10.049

Wang, R., Kalchayanand, N., Schmidt, J. W., and Harhay, D. M. (2013). Mixed biofilm formation by Shiga toxin-producing Escherichia coli and Salmonella enterica serovar Typhimurium enhanced bacterial resistance to sanitization due to extracellular polymeric substances. J. Food Prot. 76, 1513-1522. doi: 10.4315/0362-028X.JFP-13-077

Wang, W.-Z., Morohoshi, T., Ikenoya, M., Someya, N., and Ikeda, T. (2010). AiiM, a novel class of $\mathrm{N}$-acylhomoserine lactonase from the leaf-associated bacterium Microbacterium testaceum. Appl. Environ. Microbiol. 76, 2524-2530. doi: 10.1128/AEM.02738-09

Waters, C. M., and Bassler, B. L. (2005). Quorum sensing: cell-to-cell communication in bacteria. Annu. Rev. Cell Dev. Biol. 21, 319-346. doi: 10.1146/annurev.cellbio.21.012704.131001

Weiland-Bräuer, N., Kisch, M. J., Pinnow, N., Liese, A., and Schmitz, R. A. (2016). Highly effective inhibition of biofilm formation by the first metagenome-derived AI-2 quenching enzyme. Front. Microbiol. 7:1098. doi: 10.3389/fmicb.2016.01098

World Health Organization (2012). The Global View of Campylobacteriosis: Report of an Expert Consultation. Utrecht: World Health Organization. Available at: http://www.who.int/iris/handle/10665/80751

Winkelströter, L., Teixeira, F., Silva, E., Alves, V., and De Martinis, E. (2014a). Unraveling microbial biofilms of importance for food microbiology. Microb. Ecol. 68, 35-46. doi: 10.1007/s00248-013-0347-4

Winkelströter, L. K., Gomes, B. C., Thomaz, M. R. S., Souza, V. M., and De Martinis, E. C. P. (2011). Lactobacillus sakei 1 and its bacteriocin influence adhesion of Listeria monocytogenes on stainless steel surface. Food Control 22, 1404-1407. doi: 10.1016/j.foodcont.2011.02.021.

Winkelströter, L. K., Teixeira, F. B., Silva, E. P., Alves, V. F., and De Martinis, E. C. (2014b). Unraveling microbial biofilms of importance for food microbiology. Microb. Ecol. 68, 35-46. doi: 10.1007/s00248-013-0347-4

Wong, C.-S., Yin, W.-F., Choo, Y.-M., Sam, C.-K., Koh, C.-L., and Chan, K.-G. (2012a). Coexistence of quorum-quenching and quorum-sensing in tropical marine Pseudomonas aeruginosa strain MW3A. World J. Microbiol. Biotechnol. 28, 453-461. doi: 10.1007/s11274-011-0836-x

Wong, C. S., Yin, W. F., Sam, C. K., Koh, C. L., and Chan, K. G. (2012b). Characterization of wetland quorum quenching Pseudomonas aeruginosa strain 2SW8 and its 2-heptyl-3-hydroxy-4-quinolone production. New Microbiol. 35, $43-51$.
Woo, J., and Ahn, J. (2013). Probiotic-mediated competition, exclusion and displacement in biofilm formation by food-borne pathogens. Lett. Appl. Microbiol. 56, 307-313. doi: 10.1111/lam.12051

Wu, C., Lim, Ji Y., Fuller, G. G., and Cegelski, L. (2012). Quantitative analysis of amyloid-integrated biofilms formed by uropathogenic Escherichia coli at the air-liquid interface. Biophys. J. 103, 464-471. doi: 10.1016/j.bpj.2012. 06.049

Yang, F., Wang, L.-H., Wang, J., Dong, Y.-H., Hu, J. Y., and Zhang, L.-H. (2005). Quorum quenching enzyme activity is widely conserved in the sera of mammalian species. FEBS Lett. 579, 3713-3717. doi: 10.1016/j.febslet.2005.05.060

Yang, L., Liu, Y., Wu, H., Hoiby, N., Molin, S., and Song, Z.-J. (2011). Current understanding of multi-species biofilms. Int. J. Oral. Sci. 3, 74-81. doi: 10.4248/IJOS11027

Yin, X. T., Xu, L., Fan, S. S., Xu, L. N., Li, D. C., and Liu, Z. Y. (2010). Isolation and characterization of an AHL lactonase gene from Bacillus amyloliquefaciens. World J. Microbiol. Biotechnol. 26, 1361-1367. doi: 10.1007/s11274-010-0308-8

Zetzmann, M., Okshevsky, M., Endres, J., Sedlag, A., Caccia, N., Auchter, M., et al. (2015). DNase-sensitive and -resistant modes of biofilm formation by Listeria monocytogenes. Front. Microbiol. 6: 1428. doi: 10.3389/fmicb.2015. 01428

Zezzi do Valle Gomes, M., and Nitschke, M. (2012). Evaluation of rhamnolipid and surfactin to reduce the adhesion and remove biofilms of individual and mixed cultures of food pathogenic bacteria. Food Control 25, 441-447. doi: 10.1016/j.foodcont.2011.11.025

Zhang, H.-B., Wang, L.-H., and Zhang, L.-H. (2002). Genetic control of quorumsensing signal turnover in Agrobacterium tumefaciens. Proc. Natl. Acad. Sci. U.S.A. 99, 4638-4643. doi: 10.1073/pnas.022056699

Zhao, G., Wan, W., Mansouri, S., Alfaro, J. F., Bassler, B. L., Cornell, K. A., et al. (2003). Chemical synthesis of S-ribosyl-l-homocysteine and activity assay as a LuxS substrate. Bioorg. Med. Chem. Lett. 13, 3897-3900. doi: 10.1016/j.bmcl.2003.09.015

Zhou, Q., Feng, X., Zhang, Q., Feng, F., Yin, X., Shang, J., et al. (2012). Carbon catabolite control is important for Listeria monocytogenes biofilm formation in response to nutrient availability. Curr. Microbiol. 65, 35-43. doi: 10.1007/s00284-012-0125-4

Zhu, H., Liu, H. -J., Ning, S. -J., and Gao, Y. -L. (2011). A luxS-dependent transcript profile of cell-to-cell communication in Klebsiella pneumoniae. Mol. Biosyst. 7, 3164-3168. doi: 10.1039/C1MB05314K

Conflict of Interest Statement: The authors declare that the research was conducted in the absence of any commercial or financial relationships that could be construed as a potential conflict of interest.

Copyright (c) 2016 Coughlan, Cotter, Hill and Alvarez-Ordónez. This is an openaccess article distributed under the terms of the Creative Commons Attribution License (CC BY). The use, distribution or reproduction in other forums is permitted, provided the original author(s) or licensor are credited and that the original publication in this journal is cited, in accordance with accepted academic practice. No use, distribution or reproduction is permitted which does not comply with these terms. 